Araștırma Makalesi - Gönderim Tarihi: 16.09.2019 Kabul Tarihi: 28.12.2019

\title{
Marka Kișiliği Olușumunda ve Yansıtılmasında Reklamlarda Arketip Kullanımı: Türkiye'nin En Değerli İlk 10 Markasının Reklamlarına Yönelik Bir Analiz
}

\author{
Berkant YILMAZ12 \\ Bektaș SARI ${ }^{3}$
}

\begin{abstract}
Öz
Bireyler kendilerini diğer bireylerden ayırmak ve kendilerini tanımlamak için sahip oldukları kimlik özelliklerini kullanmaktadır. Bu durum, günümüzde markalar için de geçerlidir. Kendini diğer markalardan farkılaştırmak, hatırlanır ve tercih edilir bir marka olabilmek amacıyla müşterilere ürün/hizmetleri çağrıştıracak anlamlar üretmek ve bu anlamların pekiştirilmesini sağlamak, reklamcıların ve pazarlama profesyonellerinin önceliği olmuştur. Bu noktada marka kişiliğini yansıtmak için bilinçaltına yönelik reklam stratejisine başvurulmakta, ürün/hizmetlere anlam yükleme aracı olarak arketiplerden faydalanılmaktadır.
\end{abstract}

Markaların reklamlarında hangi arketiplere başvurduğunu ve bu arketipler aracılığıyla marka kişiliğinin nasıl yansıtılı̆̆ını belirlemeyi amaçlayan bu çalışmada, Margaret Mark ve Carol Pearson'un ve Carl G. Jung'ın kolektif bilinçdışı teorisini geliştirerek oluşturdukları "arketipsel markalama" modeli esas alınarak Brand Finance 2018 Türkiye raporunda ilk 10'da yer alan en değerli Türk Markalarının reklamlarına (7 marka 30 reklam) yönelik içerik analizi gerçekleştirilmiştir. Bu kapsamda markaların YouTube kanallarında 2019 yılında (1 Ocak 2019 - 1 Haziran 2019) yayınlanan reklamları analiz edilmiştir.

Araştırma sonucuna göre; Türkiye'nin en değerli ilk 10 markasının \%70’inin, incelenen tarihlerde YouTube kanallarında reklam filmi yayınladığı ve bu reklam yayınlayan markaların tamamının reklamlarında çeşitli arketiplere yer verdiği bulgularına ulaşılmıştır. Reklamlarda kullanılan arketipler markanın kendisini pazarda nasıl konumlandırdığı, hedef kitlesinin beklentileri ve sosyo-ekonomik/kültürel düzeylerine göre değişkenlik göstermektedir.

Anahtar Kelimeler: Marka Kişiliği, Reklam Stratejileri, Arketipler, Arketipsel Markalama Brand Finance 2018.

ATIF: YıImaz, B. \& Sarı, B. (2019). Marka Kișiliği Olușumunda ve Yansıtılmasında Reklamlarda Arketip Kullanımı: Türkiye'nin En Değerli ilk 10 Markasının Reklamlarına Yönelik Bir Analiz. Akdeniz Üniversitesi İletișim Fakültesi Dergisi, 32, s. 90-116

1 Öğr. Gör., Ege Üniversitesi Sosyal Bilimler Enstitüsü, berkantyilmaz@duzce.edu.tr, ORCID Numarası: 0000-0002-7309-8868 


\title{
The Use of Archetypes in Advertising in Forming and Reflecting Brand Personality: An Analysis of ads Towards Turkey's Most Valuable Brand Top 10
}

\begin{abstract}
Individuals use their identity features to distinguish themselves from other individuals and identify themselves. This also applies to brands today. It has been the priority of advertisers and marketing professionals to differentiate themselves from other brands and to produce and reinforce the meanings that will remind customers of products I services in order to become a remembered and preferred brand. At this point, advertising strategy is applied to the subconscious to reflect the brand personality and archetypes are used as a means of loading meaning to products / services.

This study aims to determine which archetypes brands use in their advertisements and how brand identity is reflected through these archetypes. Margaret Mark and Carol Pearson, formed by improving the Carl Gustav Jung's collective unconscious theory "archetypal branding" model, based on the Brand Finance 2018 report on Turkey in the first 10 in the advertisement of the most valuable Turkish brand located ( 7 brand-30 ad) for content analysis was performed. In this context, the advertisements of the brands published on YouTube channels in 2019 (1 January 2019-1 June 2019) were analysed.

According to the results of this search; Turkey's most valuable brand $70 \%$ of the first 10, which advertise the film on YouTube channel has been reached on the findings of the examination date and place given to various archetypes in all of these advertisers running brand ads. The archetypes used in advertising vary according to how the brand positions itself in the market, expectations of the target audience and socioeconomic / cultural levels.
\end{abstract}

Keywords: Brand Personality, Advertising Strategies, Archetypes, Archetypes Branding, Brand Finance 2018.

\section{Giriș}

Günümüzde markalar tıpkı bir insanın sahip olduğu gibi bir kişiliğe sahip olmak için çaba harcamaktadır. Çünkü tüketiciler ve müşteriler sadece ürün/hizmet talep etmemekte, aynı zamanda satın aldığı şeylere anlamlar yüklemektedirler. Bu bağlamda, ürün/hizmetlere, hatta markaya ruh katmak, kişilik eklemek önemli bir uğraş haline gelmiştir. Bu doğrultuda, reklamlar marka kişiliği geliştirilmesinde başvurulan, büyük role sahip araçların başında gelmektedir. Bu nedenle, pazarlama iletişimi çabalarının büyük bir kısmı reklamlar aracılığıyla marka kişiliği geliştirmeye yönelik olmaktadır. Marka kişiliğinin geliştirilmesinde sıklıkla başvurulan yöntemlerden biri de arketip kullanımıdır. Arketipler aracılığıyla markalara anlamlar, özellikler yüklenir ve markalar hikayesi olan bir kişiliğe sahip olur.

Arketipler psikanalizin önde gelen isimlerinden Carl G. Jung tarafından literatüre kazandırılmıştır. Jung'a (2006) göre bilinçaltının temel özellikleri arasında bilincin 
yanlılığın giderilmesi yer almaktadır (s. 25). Jung'un psikanalitik yaklaşımı içerisinde psişe "Freud'un psişik aygıtının yerine geçmekte olup; ego psişenin bir alt bileşeni olup; gündelik dilde "ruh" olarak ifade edilen kavramı karşılamaktadır. Bilinç, bireysel bilinç dışı ve ortak bilinç dışı (arketipal içerikler) taşıdığı işlevlerin bütünü psişe olarak tanımlanmaktadır (Jung 1916, ss. 189-191). Jung'a (2014) göre geçmişte yaşanan olayların ve durumların geçmişten geleceğe aktarımı zihinsel bir yerleşim oluşturmuştur. Ancak, bu zihinsel düzende arketipler, bireylerin geçmiş yaşantılarının bir uzantısı olan imgeler kadar net ve canlı bir biçimde yer almamaktadır. Örneğin, anne arketipi bir annenin fotoğrafı gibi canlı bir imge olarak kişilerin zihninde canlanmamaktadır. Ancak, arketipler gerçek yaşamda bir karşılık buldukları durumlarda daha canlı veya cansız varlıkların imgelemleri olarak şekillenmektedir (Jung 2014, ss. 7-15)

Markalama sürecinde arketip kullanımı kapsamında; Mark ve Pearson (2001) arketipsel marka kişiliği modeli geliştirirken; temele Jung'un ortak bilinçdışı arketip yaklaşımını benimseyerek, 12 boyuttan oluşan bir arketip sınıflandırması geliştirmiştir. Markalar da reklamlarını tasarlarken bu 12 arketipten faydalanarak tüketici zihinlerinde kendi marka kişiliklerini inşa etmekte ve pekiştirmektedirler.

Reklamlarda marka kişiliği çerçevesinde arketip kullanımına yönelik yapılan çalışmalar incelendiğinde, Yakın ve Ay (2012) giyim, teknoloji ve otomobil ürün gamları çerçevesinde gerçekleştirdikleri çalışmalarında arketip kullanımının marka kişiliklerinin tüketiciler tarafında hızlı bir biçimde anlamlandırılması üzerinde etkisi olduğunu ortaya koymuştur. Xara Brazil vd. (2018), Facebook, Apple ve Amazon'un marka kişiliği inşa süreçlerinde arketip kullanımını kültürlerarası iletişim boyutu ile analiz ettikleri çalışmalarında; markalama sürecinde arketiplerin kullanımının marka kişiliğinin inşasında etkisi olduğu sonucuna ulaşmışlardır. Araştırmacılar, ağızdan ağıza pazarlama ve marka hikayesi oluşturma sürecinde, uluslararası markların arketip kullanımının ülkelerin kültürel farklılıklarına göre önem taşıdığını saptamıştır. Conejo (2017) ise, arketip kullanımı çerçevesinde, sosyal medyanın geleneksel medyanın sınırlılıklarını aşarak, daha anlamlı ve etkileşimli içeriklerin oluşturulmasında ve marka kişiliğinin inşası açısından yüksek bir potansiyel taşıdığını ileri sürmektedir.

$\mathrm{Bu}$ bağlamda, üç bölümden oluşan çalışmanın ilk bölümünde "Kişilik ve Marka Kişiliği" kavramları açıklanmıştır. İkinci bölümünde ise "Marka Kişiliğinin Oluşumu ve Yansıtılmasında Reklamlarda Arketip Kullanımı" ele alınmıştır. Çalışmanın araştırma bölümünde ise, Mark ve Pearson'un (2001, s. 11), Carl G. Jung'ın (1980) kolektif bilinçdışı teorisini geliştirerek oluşturdukları "arketipsel markalama" modeli esas alınarak; Brand Finance 2018 Türkiye raporunda ilk 10 sırada yer alan en değerli Türk Markalarının YouTube kanallarında yayınladıkları reklamlarına yönelik içerik analizi gerçekleştirilmiştir.

\section{Kișilik ve Marka Kișiliği Kavramı}

Kişilik insana özgü bir kavram olarak ele alındığında, mizaç, karakter, zeka ve benlik gibi birçok kavramı içinde barındıran, oluşması belirli bir süreç gerektiren, dinamik bir yapıyı işaret etmektedir. Bu anlamda kişilik kavramı literatürde multidisipliner olup çeşitli tanımlamalara sahiptir. Kişiliğin anlaşılması, marka kişiliğinin anlaşılması için de 
önemli bir koşuldur.

Latince "maskelemek, gizlemek" anlamına gelen kişilik kelimesi, "persona" kelimesinden türetilmiş (Furnham ve Heaven 1999, s. 1) ve ilk olarak psikolojide kişilik kuramını oluşturan Sigmund Freud tarafından kullanılmıştır. Freud'a (1963) göre kişilik, dinamik ve çeşitlidir. En önemli özelliği ise zamana karşı dayanıklı olması ve sürekliliğini koruyabilmesidir (Akt. Azoulay ve Kapferer 2003, s. 147).

Odabaşı ve Barış (2007, ss. 189-190) ise kişiliği; kişinin iç ve dış çevresiyle kurduğu, onu diğer bireylerden ayırt eden, tutarlı ve yapılaşmış bir ilişki biçimi” olarak tanımlamaktadır.

Tüketici davranışlarını anlamak ve bu doğrultuda ürün/hizmet üreterek hedef kitleleriyle buluşturmak isteyen şirketler, sahip oldukları markalar ile; kendilerini rekabet ettikleri diğer markalardan farklılaştırmak istemektedirler. Bu doğrultuda, markalar kendilerine kişilik kazandırma çabası içerisine girmektedirler.

Kotler ve Armstrong (1989, s. 248) tarafından yapılan tanıma göre marka; üreticilerin ya da satıcıların mallarını ve hizmetlerini belirlemek, tanıtmak ve rakiplerinden farklılaştırmak amacıyla kullandıkları isimler, terimler, sözcükler, simgeler, tasarımlar, işaretler, renkler veya bunların çeşitli bileşimleri ifade etmektedir.

Yukarıdaki tanımların yanında Kotler (2000), "marka”yı altı farklı bileşene ayırmıştır. Bunlar (s. 404):

\section{-Özellikler -Değerler \\ - Yararlar -Kültür \\ -Kişilik -Kullanan (müşteri profili)}

Kotler (2000)'in ortaya koymuş olduğu marka bileşeninden kişilik kavramı, marka kimliğiyle yakından ilişkilidir. Marka kimliği Aaker (1996) tarafından, hedef kitle ile sağlanan ilişki neticesinde oluşan marka ile ilgili çağrışımların toplamından oluşan bütün olarak tanımlanmıştır. Bu kapsamda marka kişiliği, marka kimliğinin bir bileşeni konumundandır. Marka kişiliği ise, ilk olarak Gardner ve Levy tarafından 1955 yılında kullanılmış ve 1997 yılında Jeniffer Aaker tarafından listelenerek literatürde kabul görmüştür. Marka kişiliği, "marka ile anılan tüm insani karakter özellikleri” olarak tanımlanmaktadır (Aaker 1997, s. 347). Kısaca marka kişiliği; "marka bir kişi olsaydı nasıl olurdu?" sorusunun cevabıdır (Tığlı 2003, s. 68).

Markaya kişilik kazandırmanın markaya sağlayacağı faydalar aşağıdaki şekilde sıralanmaktadır (Yavuz 2004, s. 47):

-Markanın rakiplerden ayırt edilebilmesini sağlar.

-Marka ile duygusal bağ kurmayı sağlar.

-Marka reklamın etkili olmasını ve hatırlanmasını sağlar.

Tüketici zihninde marka kişiliği yaratabilmenin en etkin yolu reklamdır. Reklamlar bu noktada, soyut bir anlam ifade eden kişiliğin somutlaştırılmasına büyük katkı sağlamaktadır. 


\section{Marka Kișiliğinin Olușumu ve Yansıtılmasında Reklamlarda Arketip Kullanımı}

Çalışmanın bu kısmında, marka kişiliğinin yansıtılmasında bilinç dışına seslenen reklamlarda arketip kullanımı ve arketiplerin çağrıştırdığı marka kişiliklerine yer verilmiştir.

Holt (2003), insanların her zaman efsanelere intiyaç duyduğunu ifade etmektedir (Holt 2003, s. 44). Çünkü, kısa hikâyeler karakterlerle tamamlandığında, bu durum dünyayı daha anlamlı kılar. Ayrıca, ortak bilinçdışı, fantezilerde ve kültürel efsanelerde ortaya çıkmaktadır. Ortak bilinçdışında yer alan arketiplerin güçleri, hikâyelerin baş kahramanları ve figürleri aracılığı ile iletilmektedir (Woodside vd. 2012, s. 595).

Erken çağlarda, Platon'un, idea'nın her tür fenomenin öncesinde ve üstünde olduğu fikri herkesin malumudur. "Arketip" ise daha antik çağda bile kullanılan ve Platon'un "idea”sıyla eşanlamlı olan bir kavramdır (Jung 2005, s. 17).

Psikolojide ilk defa Carl Gustav Jung tarafından kullanılan "arketip" kavramı, kolektif bilindışını ${ }^{4}$ oluşturan öğelerdir. Ortak bilinçdışının içinde yer alan arketipler, yoğun duygusal öğeler ve enerjiler taşıyan evrensel düşünce biçimleridir. Jung (2005) arketipleri; varlığı en uzak geçmişe dayanan ilk görseller şeklinde ifade etmektedir. Arketiplerin varlığı mitolojide, peri masallarında, inanç sistemlerinde ve ilkel sanat iletilerinde de görülmektedir. Bütün arketiplerin kaynağı, aklın ilk gelişen kısmı olan ortak bilinçdışımızdır ve kolektif bilinçdışı insanlığın atalarının geçmişi ile kurması gereken bağı sağlamaktadır (Yılmaz 2018, s. 98; Yakın ve Ay 2012, s. 28).

İkna edici mesajların tasarlanmasında yaratıcı strateji, tüketici davranışını etkilemektedir. Bu bağlamda, ürüne yönelik işlevsel fayda yerine sembolik anlamların sunumu giderek yaygınlaşmaktadır. Bu kapsamda, markalar reklam mesajlarının ve içeriklerinin oluşturulmasında yaratıcı strateji unsuru olarak arketip kullanımından faydalanmaktadır.

Reklamda, efsanelerden faydalanarak oluşturulmuş kısa hikayelerle birlikte ünlü kullanımı veya animasyon karakter kullanımı gibi uygulamalar kişilik arketiplerinin ve dolayısıyla reklamda yansıtılan marka kişiliğine yönelik bir anlamın oluşturulmasına yardımcı olmaktadır. Böylece, tüketiciler satın aldıkları ürüne gizlenmiş arketipleri ve efsaneleri algılayarak markayla ilişki kurmaktadır (Holt 2003, s. 44).

Sektörel fark gözetmeksizin; arketipsel intiyaca erişebilen reklamların genellikle en ikna edici reklamlar olduğu görülmektedir. Bir reklam tasarımcısının iyi bilmesi gereken noktalardan biri; müşterisinin ürünle olan ilişkisinde hangi arketipe ihtiyaç duyduğudur. Ürünün yapısı gereği; reklamda arketipsel açıdan aynı anda birden fazla güdüleyici de rol alabilir. Örneğin; reklamda hesap yapan bir kimse bilgeliği (tavsiye) ve kaşif (keşif) arketiplerini aynı potada eritebilir (Yakın 2013, s. 94).

Arketip modelinin reklamlarda kullanılması, yalnızca insanların zihninde belli anlamların nasıl yapılandırılacağını göstermesi değil; aynı zamanda bu anlamların duygularla nasıl birleştirilebileceğine ışık tutması nedeniyle de önem taşımaktadır. Fleis-

4 Jung'un kolektif bilinçdışı kavramı, tüm insanların atalarından kalıtımsal yollarla devraldıkları ortak bir bilinçdışı olduğuna yönelik bir teoridir ve arketipler ortak bilinçdışında yer alan belirsiz simgelerdir. Arketipler aracılığı ile ilk kez karşılaştığımız kişilerin kişiliklerini hızlı bir şekilde algılayabilmekteyiz (Jung 2005'ten akt. Yakın 2013, s. 252). 
chman (1997, s. 83) gerçekleştirdiği bir araştırma sonucunda, izleyicilerin reklamlarda arketipsel görsellerle karşılaştıklarında reklama yoğun duygularla yanıt verdiklerini saptamıştır.

Carl G. Jung'un geliştirdiği kolektif bilinçdışı ve arketip teorisinden gücünü alan arketip modeli iki binli yılların başında Mark ve Pearson (2001) tarafından geliştirilmiştir. Mark ve Pearson, arketip modelini geliştirilirken on üç binden fazla marka ve yüz binden fazla tüketici üzerinde çalışma gerçekleştirerek; on iki temel arketipin marka kişiliklerini yansıtmakta kullanıldığı sonucuna ulaşmışlardır. Bu arketipler kahraman, kral, sihirbaz, yardımsever, âşık, kâşif, bilge, yaratıcı, soytarı, asi, sıradan adam ve masum arketipleridir. Mark ve Pearson (2001) tarafından belirlenen 12 arketip ve bu arketipleri yansıtan özellikler ise aşağıda belirtildiği gibidir (Faber ve Mayer 2009, s. 309; Harvey 2018; Mark ve Pearson 2001, ss. 102-111; Purkiss ve Lee 2012, s. 3; Yakın 2013, ss. 97-252; www.fabrikbrands.com, 2019; www.thehartford.com, 2019):

-Kahraman Arketipi: Savaş, atletik yarışlar, caddeler, işyerleri gibi cesaret ve enerji gerektiren, zorlukların ve mücadelenin olduğu her yerde görülür. Kahraman, dünyayı daha iyi bir yer yapmak ister. İçsel korkusu azmini yitirmek ve başarısızığa uğramaktır. Kahraman arketipinin genel özellikleri arasında cesaret, disiplin, kararılıı, rekabetçilik, engellerin üstesinden gelmek; güç görevler üstlenmek, ilham vermek, zorlukları aşmak, sorunları ahlaki doğrulukla çözmek vardır. Her birey karşılaştığı zorluklarla mücadele edebilmek için aslında kendi içinde bir kahraman taşır ve bu kahramanın cesur bir yapısı vardır. Kahramanlar, kaostan etkilenirler çünkü bu onlara kahramanlıkları için fırsat sağlar. İnandıkları şeyin arkasında dururlar. Kahraman marka arketipi, müşterileri memnun etmek için özel olarak yeni bir şey yaratmak yerine, izleyicilerinin zaten karşı karşıya olduğu adaletsizlik ve sorunların üstesinden gelmeye çalışmaktadır. Bu markalar, dünyaya başarılarından bahseder ve kendilerini kanıtlamanın yollarını ararlar. Kahraman arketipinin başarıı bir örneği olan Nike markası, sadece spor kıyafet satmamakta, müşterilerinin ilham almasını ve satın aldıkları ürünlerden güçlenmesini istemektedir. "Just Do It" sloganı içeren kampanyalarıyla Nike, sıradan insanların bile atletik idollerinin ayakkabılarını alarak ve bu ayakkabılar aracılığıyla tüm engelleri aşmalarının bir yolu olduğunu vurgulamaktadır. Doksanlı yıllarda bir spor kahramanı olarak Michel Jordan'ın Nike reklamlarında kullanııması başarılı bir ünlü kullanımına örnek teşkil etmektedir. Böylece Reklamlarla, sıradan insanların kendilerini Michael Jordan (kahraman) gibi hissetmeleri sağlanmıştır. Ayrıca, bir güdüleyici olarak birçok deterjan markasının reklamında, ev kadınlarını zorlu lekelerden, kötü mikroplardan kurtaran, koruyan ve onların yüzünü güldüren dahası kendilerini birer kahraman gibi hissetmelerini sağlayan Mr. Muscle ve Ayşe Teyze (Ace) gibi kahraman arktiplerinden sıklıkla faydalanıldığı görülmektedir.

- Yardımsever Arketipi, şefkat üzerine yoğunlaşarak, müşterilerine kendilerini takdir ve güvende hissettirecek ürünler veya hizmetler sunmaktadır. Müşterilerin konfor ve güvende olması, bu marka arketipi için önemlidir. Johnson's Baby, yardımsever markasının harika bir örneğidir. Markanın neredeyse tüm pazarlama kampanyaları, izleyicilerin ürünlerinin güvenli, markalarının ise güvenilir olduğunu bilmelerini sağlamaya dayanmaktadır.

-Aşık Arketipi, kişiliğine sahip şirketler tutkulu ve samimi özelliklere sahiptir. Güzelliğin arzusu ve takdiriyle motive edilirler ve kendilerini çekici ve lüks olarak konumlandırırlar. 
Eğer markanın ürün veya hizmeti insanların içeride ve dışarıda kendilerini iyi hissetmelerine odaklanıyorsa, o zaman 'Aşık' arketipi özelliklerini yansıtmaktadır.

- Yaratıcı Arketipi, sektördeki popüler olayların farkında olan fakat izleyicilerinin yeni bir şeyler istediğini bilen bir özelliğe sahiptir. Bu bakımdan, bu arketipe sahip markalar genellikle kendi trendlerini kendileri belirlemeye çalışmaktadırlar. Yaratıcı kişiliğin temel arzusu; uzun ömürlü bir değer ya da bir şeyler yaratmaktır ve bu arzusunu bir hayali şekillendirme amacı takip eder. Yaratıcı arketipini içeren reklamlarda sanata, tasarımsal yeniliklere vb. nitelikli görsellere yer verilir. Reklamlarda kullanılan ürünler bazen yaratıcı bir moda ürünü olabileceği gibi; bazen de tasarım harikası bir mimari yapı olabilir. Yaratıcı arketip kullanan markalara örnek olarak, Disney ve LEGO’yu göstermek mümkündür.

-Soytarı Arketipini incelediğimizde; bazı markalar kendilerini daha ciddi, dominant ve resmi konumlandırdığı, bazı markaların ise kendilerini tam tersi yönde izleyicilerle buluşturmaktadır. Bir şirketi işletmek ciddi bir iştir, ancak "soytarı" marka arketipinde, markalar eğlenceyi odaklarına almaktadırlar. Bu markalar günümüzde müşterilerinin zevk ve neşesi ile motive olmaktadır. Müşteriler ile eğlenme, ses tonuna mizah eklemek ve düzenli olarak yeni deneyimler sunmak "soytarı" arketipini destekleyen unsurlardır. Çünkü; reklam mesajının etkililiğinde mizah çekiciliği sıklıkla kullanılan stratejilerden birisidir. Bu doğrultuda, soytarı arketipi kullanımı önemli bir mizah çekiciliği unsurudur.

-Kaşif Arketipi kullanan markalar, zorluklardan korkmayan ve genellikle özgürlük ve bağımsızıık arzusu ile motive edilen bir markalardır. Bu markalar çevrelerindeki sınırları tanımalarına ve bilmelerine rağmen, bu kısıtlamaların onları durdurmasına izin vermezler. Bu nedenle, kaşif markalar sürekli sınırları zorlamaktadır.

-Bilge Arketipi, sürekli eğitim ve büyümeye odaklanan bir marka kişiliğine sahiptir. Bilge marka arketiplerinde dünyayı anlamak ve karmaşık sorunların üstesinden gelmek ön plana çıkmaktadır. Bilge arketipine en iyi örneklerden birisi Google'dir. Günümüzde erişebildiğimiz büyük miktarda bilgiyi bize sağladığından Google "bilge" arketipine uygun bir markadır. Google'ın sağladığı içeriklerle; bugünün tüketicilerine daha güçlü kararlar vermek ve en karmaşık sorularını cevaplamak için intiyaç duydukları tüm verileri sunması, bilge özelliğini destekler niteliktedir.

-Asi Arketipi, kendisini isyankar bir yapıda konumlandıran marka arketipidir. Bu marka arketipi, seçtikleri alanda statükoyu zorlamaya ve kendileri için benzersiz bir yol yaratmaya kararıdır. Bu markalar hedef kitlesi için, benzersiz bir şey yaratmak için çoğu zaman alternatif yaşam tarzlarını teşvik etmektedir. Asi marka arketipinin harika bir örneği, müşterilerine yalnızca motosikletleriyle bir ürün değil, aynı zamanda bir yaşam tarzı da sunmaya adanmış bir şirket olan Harley Davidson markasıdır.

-Kral/hükümdar Arketipini yansıtan markalar, sektördeki uzmanlıkları, başarılı liderlik becerileri ve mirasları ile gurur duyarlar. Kral marka arketipi kullanan markalar, hizmet verdikleri sektörde kendileri için üstün bir statü oluşturmayı ve pazarı kontrol etmeyi amaçlamaktadır. Bu arketipler, aynı zamanda güvenilir ve istikrarlıdırlar. Kral arketiplerinin dış imaj, statü ve prestij gibi konulara önem vermeleri onların yüzeyselliklerinden değil, görünümün ve konumun güce olan katkısını bilmelerinden kaynaklanmaktadır. Üst segment tüketici grubuna yönelik üretilen otomobil markalarının reklamlarının birçoğunda 
kral arketipinden faydalanılmaktadır. Reklamlarında genellikle güç ve üstünlük göstergelerini öne çıkaran Mercedes, bu markaların başında gelmektedir.

-Sihirbaz Arketipini yansıtan, markaların reklamlarında genellikle mucizevi çözümlere yer verilmektedir. Kimi zaman sihirli bir değnek, kimi zaman sihirbaz şapkası veya benzer bir sihirbaz karakteri yer alır. Sihirbaz arketipine sahip markalar, sihirli ufak dokunuşlarla büyük dönüşümler sunmaya çalışıllar. Daima fark yaratan teknolojik yenilikler peşindedirler.

\begin{abstract}
-Masum Arketipi, çocuk arketipinin bir yansımasıdır; bu nedenle masum arketipi denildiğinde çoğunlukla küçük çocuklar veya naif bir gençlik akla gelir. Masum arketipinin en iyi temsilcilerinden biri Porter'ın ünlü roman karakteri Pollyanna'dır. Masum, neredeyse sınırsız bir iyimserlikle ve yaşam ne getirirse getirsin sahip olduğu ümidi yaşatma azmiyle karakterize edilmiştir. Masum arketipi, yaşamın çok zor olması gerekmediği vaadinde bulunmaktadır. Güvenilir, saf, erdemli, iyimser, mutlu, olumlu, yaşamdan ümitli, alçakgönüllü ve sakin olmak masum arketipinin belirgin niteliklerindendir.
\end{abstract}

\begin{abstract}
-Sıradan Adam Arketipi ortalama insanı yansıtır. Sıradan adama, sokakta alışverişte hemen her yerde rastlamak mümkündür. Sıradan adam, daha çok alt ve bazen de eğitimsiz orta sınıf kişiler tarafından temsil edilir. Sıradan erkek ve kadınlar hallerinden memnundur. Diğerleriyle uyum ve iletişim içinde olmayı severler. Sıradan adam ve kadınlar kendilerine gülebilen ve kendileriyle dalga geçmekten de keyif alabilen insanlardır. Sıradan adam arketipine sahip markalar, tüketicilerin kendilerinden mutlu olmasını sağlamaya çalışırlar. Sıradan adam arketipinin son yıllardaki en büyük temsilcilerinden biri Unilever firmasına ait olan Dove markası da tam olarak bunu yapmaktadır. Marka ilk olarak, içeriğindeki kremler sayesinde cildi kurutmayan sabun ürünüyle pazara sunulmuş ve tüketicilere güzel bir cilt için pahalı ürünlere intiyacınız yok alt mesajını vermiştir. Sonraki yıllarda, ürün yelpazesini genişleten marka, reklam filmlerinde süper modellerden faydalanmak yerine; sıradan görünümlü kadınları oynatmıştır.
\end{abstract}

\title{
3. Yöntem
}

Çalışmanın birinci ve ikinci bölümünde, marka kişiliği ve reklamlarda marka kişiliği unsuru olarak arketip kullanımı ele aldıktan sonra, çalışmanın üçüncü ve son bölümünde Brand Finance 2018 raporu esas alınarak Türkiye'de en değerli markaların reklamları incelenmiş ve hangi arketiplere yer vererek marka kişiliklerini yansıttıkları araştırılmışır.

Araştırma kapsamında, Brand Finance 2018 raporunda ilk 10 sırada yer alan Türk markalarının reklamlarında hangi arketiplere yer verdiğini ve bu arketiplerin marka kişiliğini nasıl sunduğunu tespit edebilmek bu çalışmanın amacını oluşturmaktadır. Bu amaç doğrultusunda aşağıda yer alan şu temel araştırma sorusuna yanıt aranmıştır:

"Brand Finance 2018 raporuna göre ilk 10 sırada yer alan en değerli Türk markalarının 2019 yııının ilk yarısında YouTube kanallarında yayınladıkları reklamlarında hangi arketipler kullanılmıştır ve bu arketipler marka kişiliğini nasıl tasvir etmektedir?“

Bu araştırmanın evrenini Brand Finance 2018 Türkiye Raporunda yer alan en değerli 100 Türk Markası oluşturmaktadır. Araştırmanın örneklemi ise amaçlı örnekleme 
yöntemiyle belirlenen ve Tablo 1'de belirtilen en değerli ilk 10 Türk markasından oluşturmaktadır. Amaçlı örnekleme, bir konunun detaylı araştırılması veya seçilen duruma bağlı olarak farklı değişkenler arasında bağ kurma amacı taşıyan çalışmalarda sıklıkla yararlanılan bir örnekleme yöntemidir (Büyüköztürk vd. 2018, s. 92-93; Yıldırım ve Şimşek 2008, s.107). Bu bağlamda, çalışmanın en değerli ilk 10 Türk markası ile sınırlanmasının nedeni, farklı sektörlerde ulusal işletmelerin marka kişiliği inşa sürecinde arketip kullanımı açısından önemli veri içerikleri sunma potansiyeli taşımalarıdır. Aşağıdaki tabloda, 2018 yılının en değerli ilk 10 Türk markası yer almaktadır:

Tablo 1. 2018 Yılının En Değerli İlk 10 Türk Markası

\begin{tabular}{|c|c|c|}
\hline No & Marka Adı & Sektör \\
\hline $\mathbf{1}$ & Türk Hava Yolları & Havayolu \\
\hline $\mathbf{2}$ & Türk Telekom & Telekomünikasyon \\
\hline $\mathbf{3}$ & Turkcell & Telekomünikasyon \\
\hline $\mathbf{4}$ & Akbank & Banka \\
\hline $\mathbf{5}$ & Garanti Bankası & Banka \\
\hline $\mathbf{6}$ & Ziraat Bankası & Banka \\
\hline $\mathbf{7}$ & İş Bankası & Dayanıkı Tüketim \\
\hline $\mathbf{8}$ & Arçelik & Banka \\
\hline $\mathbf{9}$ & Yapı Kredi & Otomotiv \\
\hline $\mathbf{1 0}$ & Ford Otosan & . \\
\hline
\end{tabular}

Kaynak: Brand Finance Türkiye 2018 Yılı Raporu (https://brandfinance.com/images/upload/ brand_finance_turkey_100_2018.pdf)

Araştırma, zaman kısıtlılığı nedeni ile 01.01.2019-30.06.2019 tarihleri ile sınırlandırımıştır. Bu zaman aralığının seçilmesinin temel sebebi, Brand Finance 2018 raporuna göre en değerli 10 Türk Markasının YouTube reklamlarının uzun dönemli olarak incelenmesinin hedeflenmiş olmasıdır. İnceleme aralığı ile markaların en değerli Türk markaları olarak seçilme döneminin birbirini takip eden bir periyoda denk gelmesi de; araştırmanın sınırılıkları üzerinde etkili olmuştur. Araştırma platformu olarak çalışmanın YouTube ile sınırlandırılmasının temel nedeni ise; incelenen markaların reklam videolarını mecra üzerinde paylaşması ve platformun video ağırlıklı bir sosyal medya bileşeni olmasıdır. Bu dönem içerisinde, resmi Youtube kanallarında içerik paylaşımı gerçekleştirmeyen markaların reklamları ise, inceleme dışında tutulmuştur.

Araştırma yöntemi olarak ise içerik analizinden faydalanılmıştır. Araştırmada betimsel bir yaklaşım benimsenerek içerik analizi gerçekleştirilmiştir. İçerik analizinde konu, araştırmacının amacına, tekniğine ve yaklaşımına bağlı olarak değişebilmekle birlikte, güvenilir ve yorumlanabilir veriler sağlamaktadır (Krippendorff 2003, s. 1819). İçerik analizi çözümlemelerinde, sistemli olarak belirlenen konu ya da başlıkların metin ya da görsel içerisindeki varlığına bağlı olarak bir analiz ve sonuç çıkarımı gerçekleştirilmektedir (Balcı ve Bekiroğlu 2012, s.279). Günümüzde yeni iletişim teknolojilerinin gelişimiyle birlikte, içerik analizi metinler veya video gibi multimedya bileşenleri çerçevesinde de gerçekleştirilebilmektedir (Jensen 2011, s. 52). Bu bağlamda, Brand Finance 2018 Türkiye Raporuna göre Türkiye'nin en değerli ilk 
10 markasının YouTube kanallarında 2019 yılında (1 Ocak 2019- 1 Haziran 2019) yayınlanan reklamları içerik analizi yöntemi ile analiz edilmiştir.

Araştırmanın veri toplama yönteminden bahsedildiğinde ise; marka reklamlarının analizleri gerçekleştirilirken Mark ve Pearson'ın (2001) "Marka Kişiliği Ölçmede Kullandıkları Arketip Ölçeği”nden faydalanılmış olup, marka (kişiliği) geliştirmede kullanılan 12 (on iki) ana arketip esas alınmıştır. Bu kapsamda markaların reklamlarında marka kişiliğini yansıtması bakımından; 12 arketip arasından hangi arketiplere yer verdikleri belirlenmiştir ve betimsel bir yorumlama gerçekleştirilmiştir.

Araştırmanın kodlama formu, Mark ve Pearson'ın ölçeğinden yararlanarak "reklam adı, görsel, reklam linki”, "reklam arketipi” ve "marka Kişiliği \& Arketip İlişkisi” olmak üzere üç bölüm olarak tasarlanmıştır. Bu bağlamda; Aya ve Yakın (2017)'nin "Reklamlarla Marka Kişiliği Geliştirmek: Arketipler Tüketicileri Yakalayabiliyor Mu?" başlıklı çalışmaları, Yılmaz (2018)'in "Carl Gustav Jung'un Arketipleri Bağlamında "Persil, Magnum ve Eti Canga” Reklam Filmlerinin Çözümlemeleri” çalışması ve Conejo (2017)'nin "Improving Social Media Brand Personas Using Archetypes" çalışması temel alınarak; bu araştırmaya özel bir kodlama formu oluşturulmuştur.

Tablo 2. Mark ve Pearson'ın Geliştirdiği Marka Kişiliği Arketip Ölçeği

\begin{tabular}{|c|c|c|c|c|c|}
\hline No & Arketip & No & Arketip & No & Arketip \\
\hline $\mathbf{1}$ & $\begin{array}{c}\text { Yaratıcı } \\
\text { (Creator) }\end{array}$ & $\mathbf{5}$ & $\begin{array}{c}\text { Sıradan adam } \\
\text { (Regular Guy) }\end{array}$ & 9 & Sihirbaz (Magician) \\
\hline $\mathbf{2}$ & $\begin{array}{c}\text { Yardımsever } \\
\text { (Caregiver) }\end{array}$ & 6 & Aşık (Lover) & 10 & Masum (Innocent) \\
\hline 3 & Kral (Ruler) & 7 & Kahraman (Hero) & 11 & Kaşif (Explorer) \\
\hline 4 & $\begin{array}{c}\text { Soytarı } \\
\text { (Jester) }\end{array}$ & 8 & Asi (Outlaw) & 12 & Bilge (Sage) \\
\hline
\end{tabular}

Kaynak: (Faber ve Mayer 2009, s. 309; Mark ve Pearson 2001, s. 13). 


\section{Bulgular}

Tablo 3.Türk Hava Yolları Reklamlarında Arketip Kullanımı

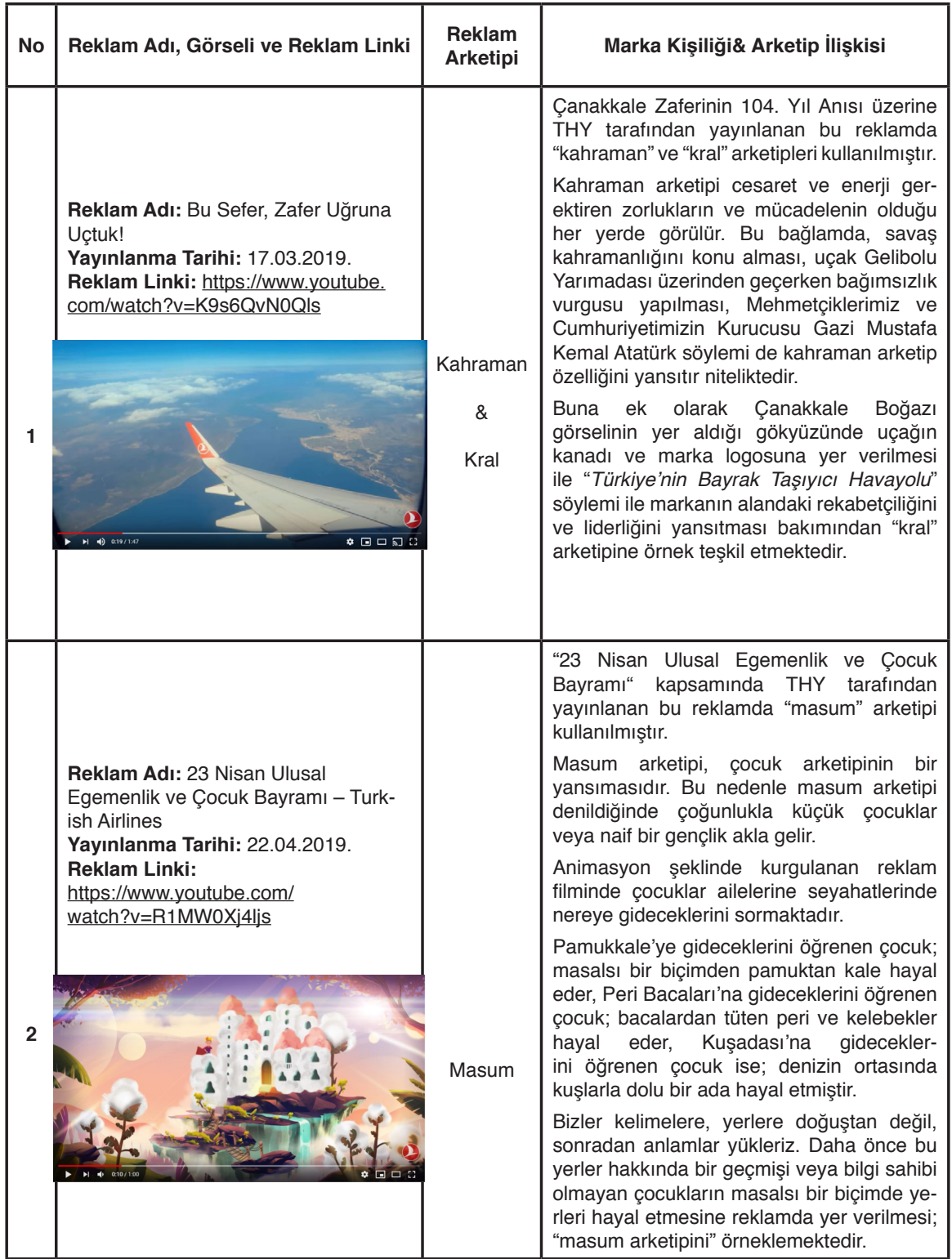




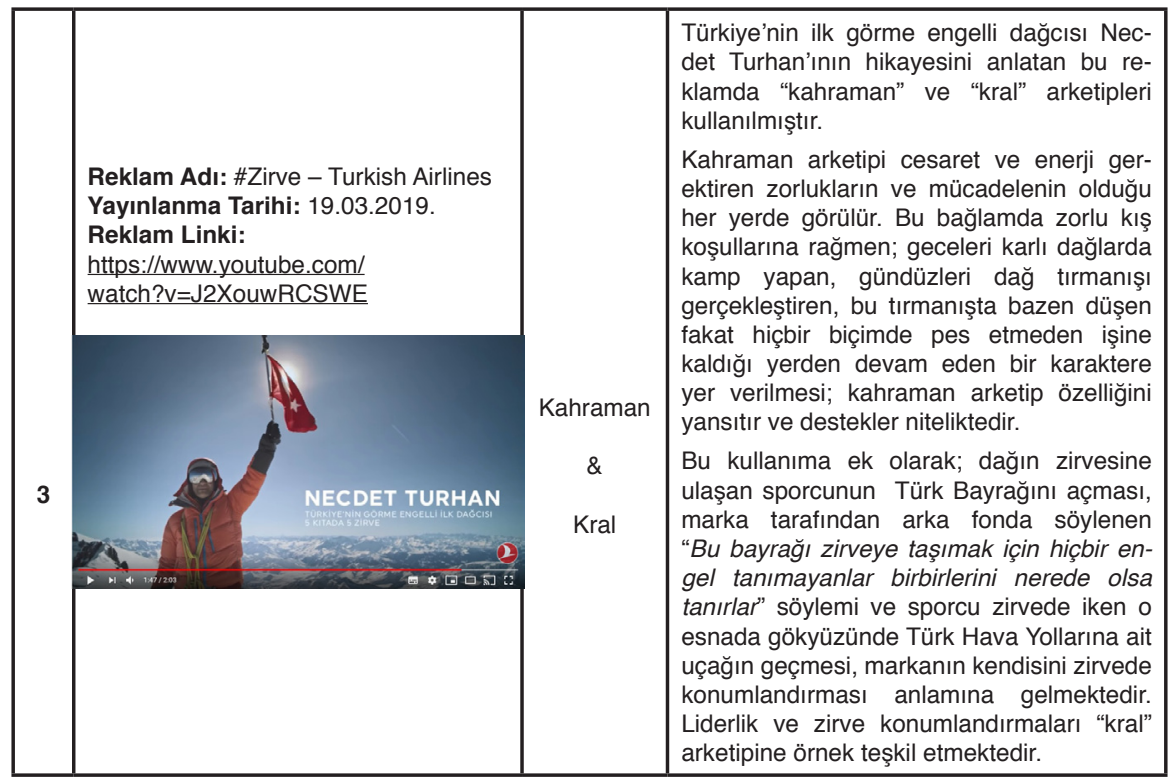

Tablo 4.Garanti Bankası Reklamlarında Arketip Kullanımı

\begin{tabular}{|c|c|c|c|}
\hline No & Reklam Adı, Görseli ve Reklam Linki & $\begin{array}{l}\text { Reklam } \\
\text { Arketipi }\end{array}$ & Marka Kişiliği\& Arketip İlişkisi \\
\hline 1 & $\begin{array}{l}\text { Reklam Adı: } 14 \text { Şubat Sevgililer } \\
\text { Günü: Kalbimiz Bir } \\
\text { Yayınlanma Tarihi: } 13.02 .2019 . \\
\text { Reklam Linki: } \\
\text { https://www.youtube.com/ } \\
\text { watch?v=AeH7d-vyU94 }\end{array}$ & $\begin{array}{c}\text { Aşık } \\
\& \\
\text { Sıradan } \\
\text { Biri }\end{array}$ & $\begin{array}{l}14 \text { Şubat Sevgililer Günü kapsamında, "Kalbi- } \\
\text { miz Bir" temasıyla Garanti Bankası tarafından } \\
\text { yayınlanan bu reklamda "aşık" ve "sıradan biri" } \\
\text { arketipleri kullanılmıştır. } \\
\text { Aşık arketipi kişiliğine sahip şirketler; tutkulu ve } \\
\text { samimidir. Ayrıca, marka insanların kendilerini } \\
\text { iyi hissetmelerine odaklanmaktadır. Sıradan } \\
\text { adam arketipi ise; ortalama insanı yansıtır. } \\
\text { Sıradan adama, sokakta, alışverişte, hemen } \\
\text { her yerde rastlamak mümkündür. } \\
\text { Garanti Bankasının bu reklamında yaşamdan } \\
\text { kesit sunularak; } 1997 \text { yılından itibaren sıradan } \\
\text { bir çalışanının bankadan emekli olduğu gün } \\
\text { izleyenleriyle paylaşmıştır. Bu durum, sıradan } \\
\text { biri arketipini yansıtmaktadır. Banka çalışanı } \\
\text { Hadiye Küstü, iş yerinden ayrılışını sevgiliden/ } \\
\text { aileden ayrıış gibi tasvir etmektedir. } \\
\text { Emekliliğe ayrılan çalışan, banka ile "gönül } \\
\text { bağının" eskiye dayandığını (güçlü geçmiş ve } \\
\text { gelenek vurgusu) ifade etmekte, babasının da } \\
\text { Garanti Bankasından emekli olduğunu, babası } \\
\text { ile annesinin düğününün banka tarafından } \\
\text { yapıldığını belirtmektedir. Bu durumun, marka } \\
\text { bağlılığı oluşturduğunu ifade etmektedir. Ayrıca, } \\
\text { kendisinin üç sevgilisi (Oğlum, Eşim ve Garanti) } \\
\text { olduğunu ifade etmesi de sevgili arketipini de } \\
\text { yansıtır niteliktedir. }\end{array}$ \\
\hline
\end{tabular}




\begin{tabular}{|c|c|c|c|}
\hline$?$ & $\begin{array}{l}\text { Reklam Adı: Bayram Ettiren Krediler } \\
\text { Garanti BBVA'da! } \\
\text { Yayınlanma Tarihi: } 13.05 .2019 . \\
\text { Reklam Linki: } \\
\text { https://www.youtube.com/ } \\
\text { watch?v=Qa3HKTPqmi4 }\end{array}$ & . & $\begin{array}{l}\text { "Bayram Ettiren Krediler Garanti BBVA'da!" } \\
\text { isimli Garanti Bankası tarafından yayınlanan bu } \\
\text { reklamda "soytarı" arketipi kullanılmıştır. } \\
\text { "Soytarı" arketipinde, markalar eğlenceyi } \\
\text { odaklarına almaktadırlar. Bu markalar } \\
\text { günümüzde müşterilerinin zevk ve neşesi ile } \\
\text { motive olmaktadır. } \\
\text { Garanti Bankasının, bu reklamında ünlü } \\
\text { kullanımına yer verilmiş olup, komedi film ve } \\
\text { dizileriyle tanınan oyuncu Engin Günaydın } \\
\text { (Ayhan Bey rolü ile) markanın reklam yüzü } \\
\text { olmuştur. } \\
\text { Ayhan Bey, kızıyla birlikte tatile gitmekten (tatil } \\
\text { masrafından) kaçmak için mizahi bir yaklaşım } \\
\text { ile mahalle bakkalıyla daha önce hiç bilmediği; } \\
\text { tavla, satranç, briç ve bilek güreşi yaparak tatile } \\
\text { gitmekten kaçmaktadır. } \\
\text { Reklamın ilerleyen sürecinde marka ikonu ha- } \\
\text { line gelen "Ugi Robotu" devreye girerek; güvenli } \\
\text { cepten bayram kredisi çekmesi tavsiyesinde } \\
\text { bulunmaktadır. Mucize bir dokunuşla fırsat } \\
\text { sunması bakımından, UGi karakteri sihirbaz ar- } \\
\text { ketipi özelliklerini de yansıtmaktadır. }\end{array}$ \\
\hline 3 & $\begin{array}{l}\text { Reklam Adı: Garanti BBVA'dan Bahar } \\
\text { Kredisi Fırsatı } \\
\text { Yayınlanma Tarihi: } 11.04 .2019 . \\
\text { Reklam Linki: } \\
\text { https://www.youtube.com/ } \\
\text { watch?v=i4tQgpOML7A }\end{array}$ & Soytarı & $\begin{array}{l}\text { "Garanti BBVA'dan Bahar Kredisi Fırsatı" isimli } \\
\text { bu reklamda "soytarı" arketipi kullanılmıştır. } \\
\text { Garanti Bankasının bu reklamında da ünlü } \\
\text { kullanımına yer verilmiş olup, Engin Günaydın } \\
\text { (Ayhan Bey rolü) markanın reklam yüzü } \\
\text { olmuştur. } \\
\text { Bir araba içinde baba-kız diyaloğu şeklinde } \\
\text { geçen bu reklamda Ayhan Bey kızına dönerek; } \\
\text { "Aç şunu da bir rahatlayalım" cümlesini kurmuş } \\
\text { ve kızı da arabanın camını mı açayım diye } \\
\text { babasına soru yöneltmiştir. Burada Ayhan Bey, } \\
\text { mizah kullanarak soytarı arketipini yansıtacak } \\
\text { şekilde kızına, "Garanti Cep'i" açmasını } \\
\text { kastettiğini gülerek söylemiştir. } \\
\text { Bu esprinin üzerine de kız, babasını överek (!) } \\
\text { (alaycı mizahi bir tavırla) "inanınızsın baba" } \\
\text { şeklinde cevap vermiştir. Reklamda kullanılan } \\
\text { bu mizahş yaklaşım; soytarı arketipi özelliklerini } \\
\text { desteklemektedir. }\end{array}$ \\
\hline
\end{tabular}




\begin{tabular}{|c|c|c|c|}
\hline 4 & $\begin{array}{l}\text { Reklam Adı: Kazançlı Tamamlayıcı } \\
\text { Sağlık Sigortası } \\
\text { Garanti BBVA'da! } \\
\text { Yayınlanma Tarihi: } 14.02 .2019 . \\
\text { Reklam Linki: } \\
\text { https://www.youtube.com/ } \\
\text { watch?v=Lg1b2faFg1M }\end{array}$ & 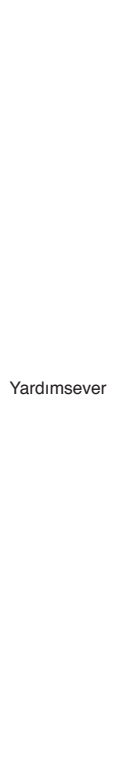 & $\begin{array}{l}\text { "Kazançlı Tamamlayıcı Sağlık Sigortası Garanti } \\
\text { BBVA'da!" isimli bu reklamda "Yardımsever" ar- } \\
\text { ketipi kullanıımıştır. } \\
\text { "Yardımsever" marka arketipleri müşterilerine } \\
\text { kendilerini güvende hissettirecek ürün/hizmetler } \\
\text { sunmaktadır. } \\
\text { Garanti Bankasının bu reklamında marka ikonu } \\
\text { haline gelen "Ugi Robotu" ve "Hemşire" karak- } \\
\text { terine yer verilmiştir. } \\
\text { Modern ile gelenekselin bir arada sunulduğu bu } \\
\text { reklamda, Ugi robotu sigorta hakkında bilgi ver- } \\
\text { irken, sağlık kuruluşlarında sessizliği sembolize } \\
\text { eden ve (Şşşşt! İşareti yapan) duvarlarda asılı } \\
\text { hemşire figürü devreye girmiş ve Ugi robotu } \\
\text { sözü hemşireye bırakmıştır. } \\
\text { SGK'ılıra özel, yatarak tedavi yılda sad- } \\
\text { ece } 199 \text { TL + \%20 bonus hediyesi sözünü } \\
\text { söyleyen hemşire, bu replikle marka vaadini } \\
\text { aktarmaktadır. } \\
\text { Ayrıca, hemşire "Herkes sağlık sigortası } \\
\text { yaptırsın diye sigortalar Garanti cepte" söylemi } \\
\text { ile de bankanın hedef kitlesini düşündüğü ve } \\
\text { onlara yardım etmek istediği vurgulamaktadır. } \\
\text { Bu yaklaşım, yardımsever arketipini yansırır } \\
\text { niteliktedir. }\end{array}$ \\
\hline
\end{tabular}

Tablo 5.Turkcell Reklamlarında Arketip Kullanımı

\begin{tabular}{|c|c|c|c|}
\hline No & Reklam Adı, Görseli ve Reklam Linki & $\begin{array}{l}\text { Reklam } \\
\text { Arketipi }\end{array}$ & Marka Kişiliği\& Arketip İlişkisi \\
\hline & $\begin{array}{l}\text { Reklam Adı: } 25 \text { yıldır geliştirdiğimiz her } \\
\text { teknoloji \#senyapdiye } \\
\text { Yayınlanma Tarihi: } 26.01 .2019 . \\
\text { Reklam Linki: } \\
\text { https://www.youtube.com/ } \\
\text { watch?v=bvxZZANvnyl }\end{array}$ & $\begin{array}{c}\text { Yaratıcı } \\
\& \\
\text { Sıradan }\end{array}$ & $\begin{array}{l}\text { "25 yıldır geliştirdiğimiz her teknoloji \#sen- } \\
\text { yapdiye ismini taşıyan ve Turkcell tarafından } \\
\text { yayınlanan bu reklamda "kahraman", "sıradan } \\
\text { adam" ve "yaratıcı" arketipleri kullanımıştır. } \\
\text { Reklamda ilk olarak "sıradan kişi arketipine" } \\
\text { yer verilerek; sıradan insanların hayatta yap- } \\
\text { maya çalıştıkları faaliyetlerde (kayak yap- } \\
\text { mak, sunum yapmak, futbol oynamak) bazen } \\
\text { başarısız olunabileceği, bu başarısızlıklarda } \\
\text { toplum tarafından olumsuz tepkilerle (güler- } \\
\text { ler, konuşurlar, izlerler) karşılaşılabileceği } \\
\text { fakat her ne olursa olsun "vazgeçmemek" } \\
\text { gerektiği vurgulanmıştır. }\end{array}$ \\
\hline 1 & 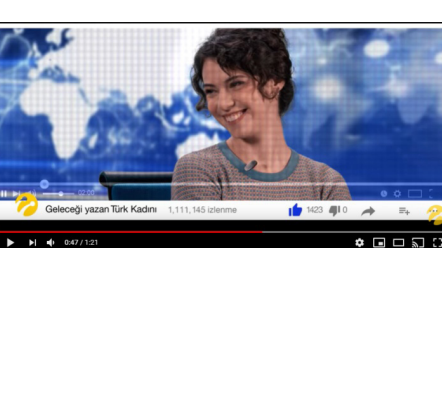 & $\begin{array}{c}\text { Biri } \\
\& \\
\text { Kahra- } \\
\text { man }\end{array}$ & $\begin{array}{l}\text { Zorluklarla mücadele edildiğinde nası } \\
\text { başarılı olunabileceği bu kişiler üzerinden } \\
\text { hikaye edilmiş ve "kahraman" arketipinden } \\
\text { yararlanılmıştır. Reklamın sonunda ise; } \\
\text { olumsuz düşünen insanların, elde edilen } \\
\text { başarıyla birlikte vazgeçmeyen kişileri } \\
\text { alkışlayacağı, takdir edeceği ve gurur } \\
\text { duyacağı, başarılı örneklerle anlatılmıştır. } \\
\text { Markanın, "Bu dünyayı her şeye rağmen } \\
\text { YAPANLAR değiştirir. Işste yaptığımız her } \\
\text { yenilik, her teknoloji bunun için: \#senyap- } \\
\text { diye" söylemi de } 25 \text { yıldır yaptığı yenilikleri } \\
\text { yansıtması bakımından "yaratıcı arketip" } \\
\text { niteliği taşımaktadır. }\end{array}$ \\
\hline
\end{tabular}




\begin{tabular}{|c|c|c|c|}
\hline 2 & $\begin{array}{l}\text { Reklam Adı: Bizi Geleceğe Taşıyacak } \\
\text { Olanlar Onlar } \\
\text { Yayınlanma Tarihi: } 21.04 .2019 . \\
\text { Reklam Linki: https://www.youtube. } \\
\text { com/watch?v=wwOapzHwiLo }\end{array}$ & $\begin{array}{c}\text { Masum } \\
\& \\
\text { Sihirbaz } \\
\& \\
\text { Yaratıcı } \\
\text { \& } \\
\begin{array}{c}\text { Kahra- } \\
\text { man }\end{array}\end{array}$ & $\begin{array}{l}23 \text { Nisan Ulusal Egemenlik ve Çocuk } \\
\text { Bayramı kapsamında yayınlanan "Bizi } \\
\text { Geleceğe Taşıyacak Olanlar Onlar" isimli bu } \\
\text { reklamda "masum", "yaratıcı" ve "sihirbaz" ar- } \\
\text { ketipleri kullanımıştır. } \\
\text { Bu reklamda, günümüzün dijital yerlileri } \\
\text { çocuklar ve dijital göçmenleri olan aileler- } \\
\text { inin çocukluklarının mizahi bir şekilde } \\
\text { karşılaştırıldığı bu reklamda; çocukların } \\
\text { teknolojiye bakışı ve kullanma biçimleri } \\
\text { yıllar içinde değişim gösterse de özlerinde } \\
\text { çocuk oldukları mesajı "masum arketipi" ile } \\
\text { sunulmuştur. } \\
\text { Sihirbaz arketipine sahip markalar, daima } \\
\text { fark yaratan teknolojik yenilikler peşindedirler. } \\
\text { Turkcell de bu reklamda günümüz } \\
\text { çocuklarının günümüz teknolojileriyle (beyin } \\
\text { sistemleri, yapay zeka, bluetooth teknolojileri } \\
\text { vb) nasıl içli dışlı olduğunu göstermekte ve } \\
\text { yenilikle odaklanarak "sihirbaz arketipi" ve } \\
\text { "yaratıcılık arketipine" yer vermektedir. } \\
\text { Markanın reklamda, çocuklar "Turkcell Zeka } \\
\text { Gücü" projesi ile yepyeni projeler geliştirip bizi } \\
\text { ileriye taşıcaklar diyerek Cumhuriyetimizin } \\
\text { kurucusu Mustafa Kemal Atatürk'ün; "Onlar } \\
\text { geleceğimizin güvencesi" sözüne yer ver- } \\
\text { ilmesi, kahraman arketipinin de kullanıldığını } \\
\text { göstermektedir. }\end{array}$ \\
\hline 3 & $\begin{array}{l}\text { Reklam Adı: Turkcell Dijital Zeka } \\
\text { Yayınlanma Tarihi: 28.01.2019. } \\
\text { Reklam Linki: https://www.youtube. } \\
\text { com/watch?v=DRVhSKutZxo }\end{array}$ & $\begin{array}{l}\text { Sihirbaz } \\
\qquad \& \\
\text { Yaratıcı }\end{array}$ & $\begin{array}{l}\text { "Turkcell Dijital Zeka" isimli bu reklamda ise } \\
\text { "masum", "yaratıcı" ve "sihirbaz" arketipleri } \\
\text { kullanılmıştır. } \\
\text { Reklamda, bir baba kızına "Kırmızı Başlıklı } \\
\text { Kız" masalını okurken, kızı anlatılanları } \\
\text { mantıklı bulmuyor ve hikayeyi dijital teknolo- } \\
\text { jilerden faydalanarak kendisi tekrar anlatıyor } \\
\text { (Bu durum günümüz çocuklarının bilgi to- } \\
\text { plumunda her şeyi daha hızlı öğrendiğini } \\
\text { göstermektedir). Markanın "Şimdiki çocuk- } \\
\text { lar her şeyi değiştirmek için geliyor" mesajı } \\
\text { da teknolojik yenilikler ve değişim söylemi } \\
\text { içermesi bakımından "sihirbaz ve "yaratıcı" } \\
\text { arketiplerini yansıtmaktadır. }\end{array}$ \\
\hline 4 & $\begin{array}{l}\text { Reklam Adı: Son Teknoloji Ürünler } \\
\text { Turkcell'de } \\
\text { Yayınlanma Tarihi: } 15.03 .2019 . \\
\text { Reklam Linki: https://www.youtube. } \\
\text { com/watch?v=ZYRpTgpGeKY }\end{array}$ & $\begin{array}{c}\text { Sıradan } \\
\text { Biri } \\
\text { Sihirbaz } \\
\text { \& } \\
\text { Yaratıcı }\end{array}$ & $\begin{array}{l}\text { "Son Teknoloji Ürünler Turkcell'de" isimli bu } \\
\text { reklamda "masum", "yaratıcı" ve "sihirbaz" } \\
\text { arketipleri kullanılmıştır. } \\
\text { Reklamda, zaman içerisinde teknoloji ile } \\
\text { dönüşüme uğrayan günlük yaşam ritüel- } \\
\text { lerine (Aşkını drone ve emojiler ile ilan } \\
\text { etmek, sınavları kağıt yerine tabletlerde } \\
\text { yapmak, iş yerlerini sanal ortamda açmak } \\
\text { vb.) yer verilmiştir. Bu reklamda, sıradan } \\
\text { yaşamdan örnekler sunulması bakımından } \\
\text { "sıradan kişi arketipi" kullanılmıştır. Reklam } \\
\text { mesajında, "her gün yenilenen bu düny- } \\
\text { adan kimse geri kalmasın diye son teknoloji } \\
\text { ürünlerinin Turkcell'de olduğu ve Turkcell'in } \\
\text { bu yüzden var olduğunun" ifade edilm- } \\
\text { esi teknolojik yeniliği ve değişimi içermesi } \\
\text { bakımından "yaratıcı ve sihirbaz" arketiplerini } \\
\text { yansıtmaktadır. }\end{array}$ \\
\hline
\end{tabular}


Tablo 6.Türk Telekom Reklamlarında Arketip Kullanımı

\begin{tabular}{|c|c|c|c|}
\hline No & Reklam Adı, Görseli ve Reklam Linki & $\begin{array}{l}\text { Reklam } \\
\text { Arketipi }\end{array}$ & $\begin{array}{c}\text { Marka Kişiliği \& } \\
\text { Arketip İlişkisi }\end{array}$ \\
\hline 1 & $\begin{array}{l}\text { Reklam Adı: "Naime sen bi dur artık } \\
\text { ben paylaşıcam" } \\
\text { Yayınlanma Tarihi: 29.05.2019 } \\
\text { Reklam Linki: } \\
\text { https://www.youtube.com/ } \\
\text { watch?v=E484UpfqNac }\end{array}$ & $\begin{array}{l}\text { Sıradan } \\
\text { Adam } \\
\qquad\end{array}$ & $\begin{array}{l}\text { Türk Telekom'a ait } 29.05 .2019 \text { tarihinde } \\
\text { yayınlanan "Naime sen bi dur artık ben } \\
\text { paylaşıcam" isimli reklam filminde "Sıradan } \\
\text { Adam" ve "Yardımsever" arketipleri kullanı- } \\
\text { mıştır. Reklam filminde İnternet paketinde } \\
\text { yeterli miktarda kotası olmayan ve "sıradan" } \\
\text { (orta gelir düzeyine sahip) bir tüketicinin ya- } \\
\text { şadıkları, yapmak istedikleri ama ekonomik } \\
\text { sıkıntıları nedeniyle yapamadıkları anlatı- } \\
\text { maktadır. } \\
\text { Toplumun çoğunluğunu oluşturan sıradan } \\
\text { adam arketipi modeli kullanarak marka, tü- } \\
\text { ketici ile marka kişiliği arasında bağ kurma } \\
\text { yoluna gitmektedir. Yardımsever arketipinde } \\
\text { ise marka tüketiciye sunduğu çözüm önerisi } \\
\text { ile (burada internet paketinin yeterli gelme- } \\
\text { mesi problemine daha büyük kapasiteli pa- } \\
\text { ket önerisi sunulması) hem rakip firmalarla } \\
\text { olan farkını ortaya koymaya çalışmakta; } \\
\text { hem de yardımsever görünmektedir. }\end{array}$ \\
\hline 2 & $\begin{array}{l}\text { Reklam Adı: "Elir } \\
\text { Yayınlanma Tari } \\
\text { Reklam Linki:htt }\end{array}$ & $\begin{array}{c}\text { Siradan } \\
\text { Adam }\end{array}$ & $\begin{array}{l}\text { Türk Telekom, } 2019 \text { yılının Mayıs ayında } \\
\text { gösterilmeye başlayan "elini korkak alış- } \\
\text { tırma" reklamında "Sıradan Adam" arketipi } \\
\text { kullanılmışıı. } \\
\text { Sıradan adam arketipi "vatandaş" terimi- } \\
\text { ne karşıı gelir ve sessiz çoğunluğu tem- } \\
\text { sil eder. Bu reklam filminde de orta gelir } \\
\text { düzeyine sahip, toplumun çoğunluğunu } \\
\text { oluşturan bireylerin sıklıkla karşılaştıkları } \\
\text { problemlerden bir tanesi olan İternet pa- } \\
\text { ketinin bitmesi problemine karşı, marka } \\
\text { uygun ücretlendirme yaparak kendisini } \\
\text { "vatandaş"ın yanında konumlandırmıştır. } \\
\text { Reklamda yer alan oyuncuların ortak özel- } \\
\text { likleri toplumun genel özelliklerini yansıtan } \\
\text { çoğunluğa ait olmalarıdır. }\end{array}$ \\
\hline 3 & $\begin{array}{l}\text { Reklam Adı: "Herkes Telekom'da } \\
\text { Türk Telekom'da" } \\
\text { Yayınlanma Tarihi: } 15.05 .2019 \\
\text { Reklam Linki: https://www.youtube. } \\
\text { com/watch?v=z1xz0 rktZg }\end{array}$ & $\begin{array}{l}\text { Siradan } \\
\text { Adam }\end{array}$ & $\begin{array}{l}\text { Türk Telekom'a ait } 15.05 .2019 \text { tarihin- } \\
\text { de yayınlanan "Herkes Telekom'da Türk } \\
\text { Telekom'da" reklam filminde de yine "Sıra- } \\
\text { dan Adam" arketipi kullanılmıştır. } \\
\text { Toplumun çoğunluğunun problemi olarak } \\
\text { vurgulanan İnternet tarifesi problemini gi- } \\
\text { dermek için çözüm önerisi sunan ve tüke- } \\
\text { ticilerinin yanında olduğunu vurgulayan } \\
\text { marka; reklam filminde, "sıradan", yani ünlü } \\
\text { olmayan oyuncuları kullanmış, kendisini } \\
\text { toplumun çoğunluğunun yanında konum- } \\
\text { landırmıştır. }\end{array}$ \\
\hline
\end{tabular}




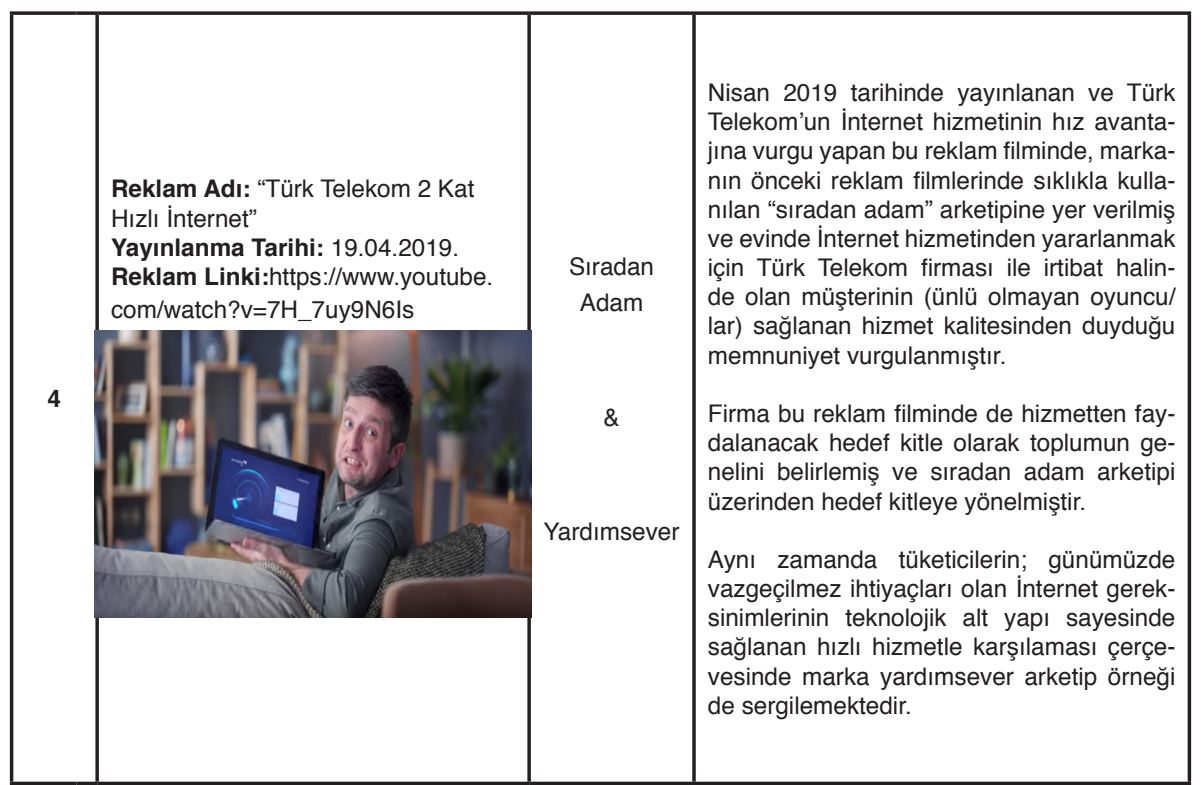

Tablo 7. Akbank Reklamlarında Arketip Kullanımı

\begin{tabular}{|c|c|c|c|}
\hline No & Reklam Adı, Görseli ve Reklam Linki & $\begin{array}{l}\text { Reklam } \\
\text { Arketipi }\end{array}$ & Marka Kişiliği\& Arketip İlişkisi \\
\hline 1 & $\begin{array}{l}\text { Reklam Adı: "Ertelemeli Bayram Kredi- } \\
\text { niz Akbank'ta" } \\
\text { Yayınlanma Tarihi: } 21.05 .2019 \\
\text { Reklam Linki: } \\
\text { https://www.youtube.com/watch?V=WY- } \\
\text { gNorHR-I }\end{array}$ & Yardımsever & $\begin{array}{l}\text { Akbank tarafından yayınlanan "Ertel- } \\
\text { emeli Bayram Krediniz Akbank'ta" re- } \\
\text { klam filminde "yardımsever" arketipi } \\
\text { kullanılmıştır. } \\
\text { Yardımsever arketipin temelinde insan- } \\
\text { lara iyilik yapmaktan mutluluk duymak } \\
\text { yatar. İnsanlara yardımcı olmak, onları } \\
\text { desteklemek, problemlerini gidermek } \\
\text { gibi misyonlara sahip olan yardımsever } \\
\text { arketipi; söz konusu reklam filminde } \\
\text { bayram zamanında para veya krediye } \\
\text { ihtiyaç duyan müşterilere bahsedilen } \\
\text { alanlarda yardımcı olmak üzerinden } \\
\text { oluşturulmuştur. }\end{array}$ \\
\hline
\end{tabular}




\begin{tabular}{|c|c|c|c|}
\hline 2 & $\begin{array}{l}\text { Reklam Adı: "Akbank - Güveninizin } \\
\text { Eseri" } \\
\text { Yayınlanma Tarihi: 11.02.2019. } \\
\text { Reklam Linki: https://www.youtube. } \\
\text { com/watch?v=jgTrozBQUdU }\end{array}$ & $\begin{array}{c}\text { Bilge } \\
\text { Arketipi }\end{array}$ & $\begin{array}{l}\text { Şubat } 2019 \text { 'da yayınlanan Akbank'ın bu } \\
\text { reklam filminde "güven" vurgusuyla "bilge } \\
\text { arketipi" üzerinden yapılmıştır. } \\
\text { Bilge arketipinden yararlanan markalar; } \\
\text { müşterilerine tecrübe ve deneyimleri } \\
\text { üzerinden elde ettikleri bilgilere } \\
\text { dayanarak bilimsel ve bazen de } \\
\text { teknik açılardan farklı çözüm önerileri } \\
\text { sunmaktadırlar. Insan, doğası gereği, bil- } \\
\text { inmezden uzaklaşma ve bilinene, güven } \\
\text { verene doğru yönelme eğilimindedir. } \\
\text { Bahsedilen arketip ile marka tüketicilerin } \\
\text { güvenlerini kazanma amacıyla reklam } \\
\text { stratejisini oluşturmuş ve uygulamaya } \\
\text { geçmiştir. }\end{array}$ \\
\hline 3 & $\begin{array}{l}\text { Reklam Adı: “Ihtiyaç Anında Krediniz } \\
\text { Akbank'ta” } \\
\text { Yayınlanma Tarihi: 08.02.2019 } \\
\text { Reklam Linki: https://www.youtube. } \\
\text { com/watch?v=WY-gNorHR-ı }\end{array}$ & Yardımsever & $\begin{array}{l}\text { Akbank tarafından yayınlanan "intiyaç } \\
\text { Anında, Krediniz Akbank'ta" reklam film- } \\
\text { inde "yardımsever" arketipi kullanılmıştır. } \\
\text { Bu arketipin temelinde, insanlara iyi- } \\
\text { lik yapmaktan mutluluk duymak ya- } \\
\text { tar. İnsanlara yardımcı olmak, onları } \\
\text { desteklemek, problemlerini gidermek gibi } \\
\text { misyonlara sahip olan yardımsever ar- } \\
\text { ketipi söz konusu reklam filminde krediye } \\
\text { intiyaç duyan müşterilere bahsi geçen } \\
\text { alanlarda yardımcı olmak savı üzerinden } \\
\text { oluşturulmuştur. }\end{array}$ \\
\hline
\end{tabular}


Tablo 8. Ziraat Bankası Reklamlarında Arketip Kullanımı

\begin{tabular}{|c|c|c|c|}
\hline No & Reklam Adı, Görseli ve Reklam Linki & $\begin{array}{l}\text { Reklam } \\
\text { Arketipi }\end{array}$ & Marka Kişiliği \& Arketip İlişkisi \\
\hline 1 & $\begin{array}{l}\text { Reklam Adı: “Ziraat Bankası -Online } \\
\text { Kanallar Serisi” } \\
\text { Yayınlanma Tarihleri: 22.05.2019 } \\
\text { Reklam Linkleri; } \\
\text { https://www.youtube.com/ } \\
\text { watch?v=e3WzLLxRLjk } \\
\text { https://www.youtube.com/ } \\
\text { watch?v=xZATTqS1mXY } \\
\text { https://www.youtube.com/ } \\
\text { watch?v=zolqptfAMUM }\end{array}$ & Sihirbaz & $\begin{array}{l}\text { Ziraat bankasına ait üç adet reklam filmi } \\
\text { serisi } 22 \text { mayıs } 2019 \text { tarihinde göster- } \\
\text { ilmeye başlanmıştır. Seri olarak göster- } \\
\text { ilen reklam filmlerinde "sihirbaz" arketipi } \\
\text { kullanılmıştır. } \\
\text { Sihirbazarketipi, cihazların nasıl çalıştığını } \\
\text { ve geliştirilebileceklerini araştırır. Doğal } \\
\text { güçlerle, dönüşüm ve başkalaşıla çok } \\
\text { ilgilidir. Değişimin ve pratik uygulamaların } \\
\text { hayatımızı nasıl kolaylaştıracağını anlatır. } \\
\text { Yan tarafta linkleri verilen reklam } \\
\text { filmlerinde de Ziraat Bankası online } \\
\text { işlemlerinin kolaylığı vurgulanmış, } \\
\text { bankanın altyapısının teknolojiye adapte } \\
\text { olduğunun altını çizmiş, dijitalleşmenin } \\
\text { getirdiği kolaylıkların tüketicilerinin } \\
\text { hayatlarını kolaylaştıracak şekilde ürün } \\
\text { ve hizmetlerine adapte ettiklerinden } \\
\text { bahsetmişlerdir. }\end{array}$ \\
\hline 2 & $\begin{array}{l}\text { Reklam Adı: "Ziraat Bankası - } \\
\text { Bankkart Başak" } \\
\text { Yayınlanma Tarihi: } 20.03 .2019 . \\
\text { Reklam Linki: https://www.youtube. } \\
\text { com/watch?v=ZwlOKppOIUM }\end{array}$ & Yardımsever & $\begin{array}{l}\text { Ziraat Bankası tarafından } 20 \text { Mart } 2019 \\
\text { tarihinde yayınlanan "Bankkart Başak" } \\
\text { reklamında ise bir banka kartının kullanım } \\
\text { faydalarından yani kartı kullanan tüketi- } \\
\text { cinin kazanımlarından bahsedilmektedir. } \\
\text { Burada atıfta bulunulan arketip } \\
\text { "yardımsever" arketipidir. Yardımsever ar- } \\
\text { ketipi, insanlara iyilik yapmaktan mutluluk } \\
\text { duymak, insanlara yardımcı olmak, onları } \\
\text { desteklemek, problemlerini gidermek gibi } \\
\text { misyonlara sahiptir. Söz konusu reklam } \\
\text { filminde girişimci iki arkadaşın süreci daha } \\
\text { rahat atlatabilmesine yardımc olacak } \\
\text { özellikler ile vurgulanmıştır. }\end{array}$ \\
\hline
\end{tabular}




\begin{tabular}{|c|c|c|c|}
\hline & $\begin{array}{l}\text { Reklam Adı: "Ziraat Bankası - } \\
\text { Seracılık Kredi Paketi" } \\
\text { Yayınlanma Tarihi: } 19.02 .2019 \\
\text { Reklam Linki: https://www.youtube. } \\
\text { com/watch?v=2hg9zTqi8NY }\end{array}$ & & $\begin{array}{l}\text { Ziraat Bankası tarafından } 19 \text { Şubat } \\
2019 \text { tarihinde yayınlanan "Seracılık Pa- } \\
\text { keti" reklamında, seracılık ile uğraşan } \\
\text { üreticilerin yeni girişimlerde bulunabilme- } \\
\text { leri, seracılık sektörünün gelişiminin } \\
\text { sağlanabilmesi için banka tarafından } \\
\text { hazırlanan paketler hizmete sunulmuştur. }\end{array}$ \\
\hline 3 & $\Sigma$ y & Yardımsever & $\begin{array}{l}\text { Burada atıfta bulunulan arketip } \\
\text { "yardımsever" arketipidir. Özünde insan- } \\
\text { lara iyilik yapmaktan mutluluk duymak, } \\
\text { insanlara yardımcı olmak, onları destekle- } \\
\text { mek, problemlerini gidermek gibi misyon- } \\
\text { lara sahip olan yardımsever arketipi, söz } \\
\text { konusu reklam filminde kredi imkanları ve } \\
\text { ödeme kolaylıkları ile ilgili teknik detaylar } \\
\text { üzerinden yansıtılmıştır. }\end{array}$ \\
\hline & $\begin{array}{l}\text { Reklam Adı: "Ziraat Bankası - Katkı } \\
\text { Paylı Konut Kredisi" } \\
\text { Yayınlanma Tarihi: 09.01.2019. } \\
\text { Reklam Linki: } \\
\text { h t t p s: / / w w w . y o u t u b e . c o m / } \\
\text { watch?v=AGlcJCNV-dw }\end{array}$ & Yardımsever & $\begin{array}{l}\text { Ziraat Bankası tarafından } 9 \text { Ocak } 2019 \\
\text { tarihinde yayınlanan "Katkı Paylı Konut } \\
\text { Kredisi" reklamında, konut sahibi olmak } \\
\text { isteyen tüketicilere yönelik konut kredisi } \\
\text { imkanlarından bahsedilmektedir. } \\
\text { Bu reklam filminde de, banka } \\
\text { "yardımsever" arketipi üzerinden re- } \\
\text { klam filmini sunmakta ve tüketici zih- } \\
\text { ninde marka kişiliği "yardımsever" olarak } \\
\text { konumlandırılmaktadır. Ayrıca; reklam } \\
\text { filminde faiz oranlarının detaylı verilm- } \\
\text { esi, rakamların kullanılması da reklamın } \\
\text { inanıırığını arttırmaktadır. }\end{array}$ \\
\hline
\end{tabular}

Tablo 9.Arçelik Reklamlarında Arketip Kullanımı

\begin{tabular}{|c|c|c|c|}
\hline No & Reklam Adı, Görseli ve Reklam Linki & $\begin{array}{l}\text { Reklam } \\
\text { Arketipi }\end{array}$ & Marka Kişiliği \& Arketip İlişkisi \\
\hline 1 & $\begin{array}{l}\text { Reklam Adı: "Milyonların Sevgilisi } \\
\text { Arçelik Telve Yenilendi" } \\
\text { Yayınlanma Tarihi: 21.05.2019 } \\
\text { Reklam Linki: } \\
\text { https://www.youtube.com/ } \\
\text { watch?v=Yj2w9vaw1gM\&t=2s }\end{array}$ & Sihirbaz & $\begin{array}{l}21 \text { Mayıs } 2019 \text { tarihinde yayınlanan } \\
\text { "milyonları sevgilisi Arçelik telve } \\
\text { yenilendi" reklam filminde arketip olarak } \\
\text { "sihirbaz" arketipi kullanılmıştır. Sihirbaz } \\
\text { arketipi; değişik ve pratik uygulamaları } \\
\text { kısa yoldan elde etmeyi, neredeyse mu- } \\
\text { cizevi sonuçlara ulaşmayı vaat eder ve } \\
\text { tüketicileri bu hayalle besler. Özellikle } \\
\text { teknoloji markaları, bu arketipi kullanma } \\
\text { eğilimindedir. } \\
\text { Arçelik'e ait kahve makinesi reklamında, } \\
\text { öncelikle kahvenin üretim sürecinden } \\
\text { ve ilklerinden bahsedilmiş; daha sonra } \\
\text { markaya ait ürüne atıfta bulunularak, } \\
\text { büyük bir emek ve tecrübe isteyen kahve } \\
\text { pişirme eyleminin Arçelik'e ait ürün ile } \\
\text { kolaylıkla (sihirli bir şekilde) yapılabildiği } \\
\text { vurgulanmıştır. }\end{array}$ \\
\hline
\end{tabular}




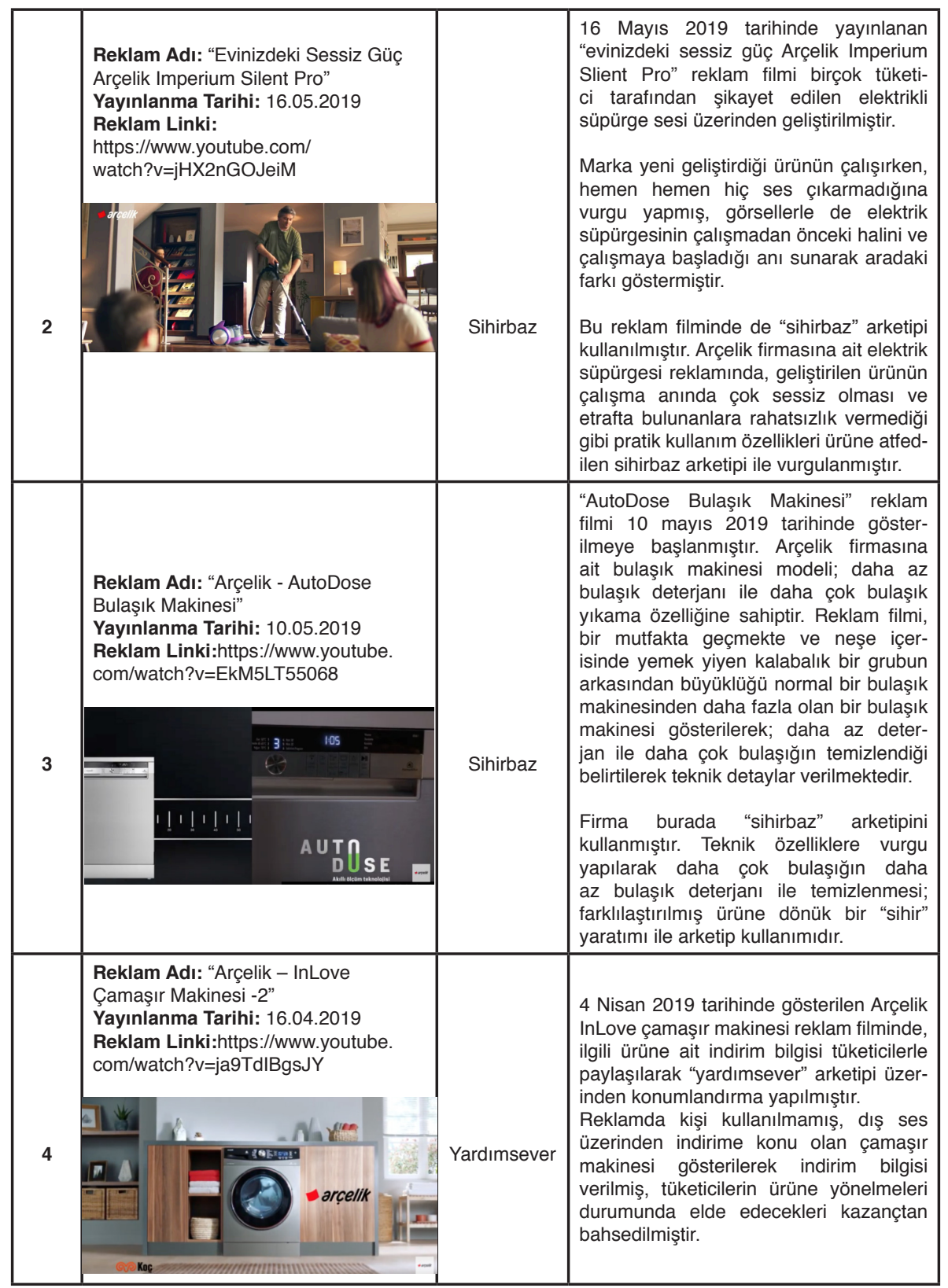




\begin{tabular}{|c|c|c|c|}
\hline 5 & $\begin{array}{l}\text { Reklam Adı: "Arçelik - InLove } \\
\text { Çamaşır Makinesi -1" } \\
\text { Yayınlanma Tarihi: } 12.04 .2019 \\
\text { Reklam Linki:https://www.youtube. } \\
\text { com/watch?v=39iAnqDhJf8 }\end{array}$ & Yaratıcı & $\begin{array}{l}12 \text { Nisan } 2019 \text { tarihinde gösterilmeye } \\
\text { başlanan InLove çamaşır makinesi } \\
\text { reklam filminde; şık giyimli üç kişinin } \\
\text { gösteriminin ardından tasarımı ve mod- } \\
\text { ern görünümüne vurgu yapılan ürün gös- } \\
\text { terilmektedir. Özellikle estetik tarafı vur- } \\
\text { gulanan ürün için; marka reklam filminde } \\
\text { "yaratıcı arketipini kullanmıştır. Yaratıcı } \\
\text { arketipinin özelliği yeniliği, güzelliği ve } \\
\text { estetik bir standardı arayan bir hayalper- } \\
\text { est olmasıdır. InLove serisine ait reklam } \\
\text { filminde, özellikle çamaşır makinesinin } \\
\text { tasarımına, estetik özelliklerine vurgu } \\
\text { yapıldığı için; yaratıcı arketipi kullanıldığı } \\
\text { görülmektedir. }\end{array}$ \\
\hline 6 & $\begin{array}{l}\text { Reklam Adı: "Arçelik Solar Panel } \\
\text { Sistemleri" } \\
\text { Yayınlanma Tarihi: 12.04.2019 } \\
\text { Reklam Linki:https://www.youtube. } \\
\text { com/watch?v=VLbYRmLW8UA }\end{array}$ & $\begin{array}{c} \\
\text { Yardımsever } \\
\text { \& } \\
\text { Sihirbaz }\end{array}$ & $\begin{array}{l}\text { Arçelik firmasına ait ve } 12 \text { Nisan } 2019 \\
\text { tarihinde gösterilmeye başlanan "Solar } \\
\text { Panel Sistemleri" tanıtım reklamında ise } \\
\text { ağırlıklı olarak "yardımsever" ve "sihir- } \\
\text { baz" arketipleri kullanılmıştır. Ülkemi- } \\
\text { zin bulunduğu konum itibariyle güneş } \\
\text { enerjisinden faydalanmaya en uygun } \\
\text { ülkelerden bir tanesi olduğunu vurgulan } \\
\text { reklam filmi, sabit giderlerden olan elektrik } \\
\text { harcamaları konusunda tüketicilere } \\
\text { yardımcı olması amacıyla tasarlanan } \\
\text { güneş panellerinden ve kullanım sonucu } \\
\text { elde edilecek kazançlardan bahsederek; } \\
\text { öncelikle yardımseverlik arketipini } \\
\text { kullanmaktadır. Bunun yanında, teknik } \\
\text { konular üzerinden detay verilen reklam } \\
\text { filminde tüketicilerin hayatında meydana } \\
\text { gelecek olan değişim ve kolaylıklardan } \\
\text { bahsedilerek de "sihirbaz" arketipi } \\
\text { kullanımı sağlanmıştır. }\end{array}$ \\
\hline 7 & $\begin{array}{l}\text { Reklam Adı: "Arçelik - Bunun Neresi } \\
\text { Küçük?" } \\
\text { Yayınlanma Tarihi: } 30.01 .2019 \\
\text { Reklam Linki: } \\
\text { https://www.youtube.com/ } \\
\text { watch?v=fJ6g6eFB1xA }\end{array}$ & $\begin{array}{c}\text { Yaratıcı } \\
\& \\
\text { Yardımsever } \\
\& \\
\text { Sihirbaz }\end{array}$ & $\begin{array}{l}\text { Özellikle mutfakta kullanılan evaletleri için } \\
\text { "küçük ev aleti” ifadesi kullanılmaktadır. } \\
\text { Arçelik markası bu ifade üzerinden } \\
\text { ürünlerin özelliklerini vurgulayan bir } \\
\text { reklam serisi hazırlamıştır. Seride yer } \\
\text { alan reklamların bir arada gösterildiği } \\
\text { ve } 30 \text { Ocak } 2019 \text { tarihinde gösterilmeye } \\
\text { başlanan reklam filminde, firmaya ait } \\
\text { ürünlerden seçilen kahve makinesi, elek- } \\
\text { trik süpürgesi, ütü, blender, tost makinesi } \\
\text { benzeri ürünlerin boyutlarının küçük ama } \\
\text { sağladıkları faydanın büyük olduğundan } \\
\text { bahsedilirken "yaratıcı, yardımsever ve } \\
\text { sihirbaz arketiplerinin" kullanıldığı görül- } \\
\text { mektedir. } \\
\text { Reklam filminde ilgili ürünlerin "küçük" } \\
\text { olmadığı vurgusu yapılırken teknolojik } \\
\text { özelliklerinden ve rakiplerine karşı ürün- } \\
\text { lerin üstün özelliklerinden de bahsedilm- } \\
\text { esi yaratıcı arketipinin yanında sihirbaz } \\
\text { arketipi kullanıldığını da göstermektedir. }\end{array}$ \\
\hline
\end{tabular}




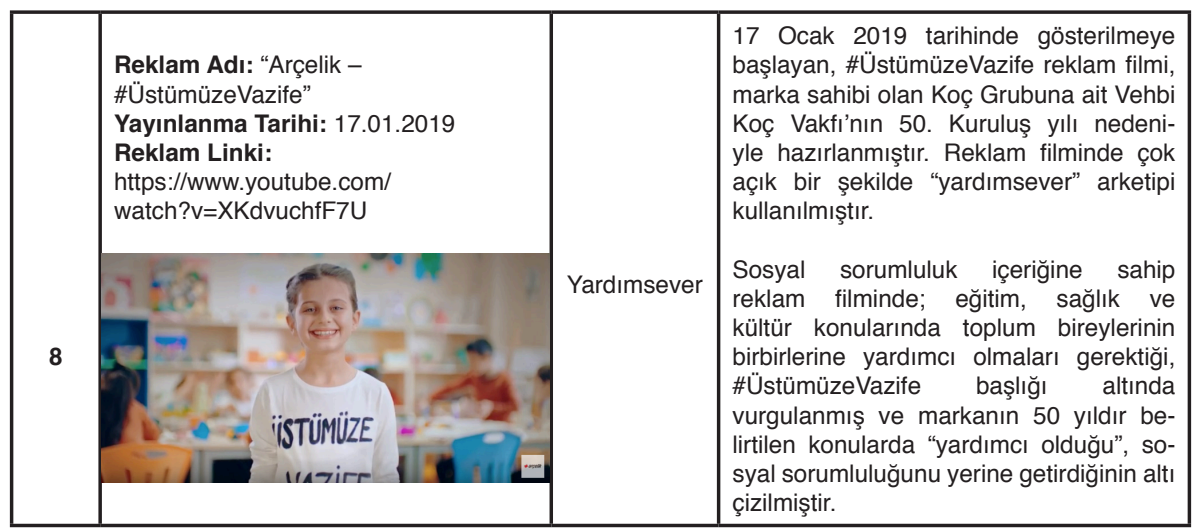

\section{Tartıșma}

Brand Finance 2018 raporuna göre ilk 10 sırada yer alan en değerli Türk markalarının 2019 yılının ilk yarısında YouTube kanallarında yayınladıkları reklamlarında hangi arketipler kullanılmıştır ve bu arketipler marka kişiliğini nasıl tasvir etmektedir? Araştırma sorusunun yanıtının arandığı bu çalışmada;

-Türk Hava Yolları markasının, "kahraman, kral ve masum" arketiplerine reklamlarında yer vererek marka kişiliği yansıttığı sonucuna ulaşılımıştır.

-Garanti Bankasının, "soytarı ve yardımsever" arketiplerine reklamlarında yer vererek, özellikle de soytarı arketipini ön plana çıkartarak mizahi yanı kuvvetli bir marka kişiliği algısı oluşturmaya çalıştığı saptanmıştır.

-Turkcell, sihirbaz, yaratıcı, kahraman, masum ve sıradan arketiplerine reklamlarında yer vermektedir. Özellikle teknolojik yenilik ve dönüşüm vurgusu yapması bakımından sihirbaz ve yaratıcı arketipleri daha ön plana çıkardığı tespit edilmiştir.

-Türk Telekom ise reklamlarında genel olarak sıradan adam ve yardımsever arketiplerine yer verdiği sonucuna ulaşılmıştır. Bu durumun markanın hitap ettiği hedef kitlenin sosyo-kültürel yapısıyla yakından ilişkili olduğu şeklinde yorumlama getirilebilir.

-Akbank, reklamlarında genel olarak yardımsever ve bilge arketiplerine yer verdiği görülmektedir. Bu bağlamda, Markanın daha çok yardımsever arketipini ön plana çıkararak, hedef kitlesine yardımcı olmayı amaçladığına yönelik mesaj iletme çabasında olduğu düşünülmektedir.

-Ziraat Bankası'nın ise, reklamlarında yardımsever ve sihirbaz arketiplerini kullanarak marka kişiliklerini yansıttığı; özellikle markanın yardımsever yönünü ön plana çıkardığı tespit edilmiştir.

-Arçelik ise, yardımsever, yaratıcı, sihirbaz, arketiplerine yer vermekle birlikte teknolojik yeniliklere dayalı yeni ürünler sunması bakımından özellikle 
sihirbaz ve yaratıcı arketiplerini ön plana çıkartarak marka kişiliğini inşa ettiği saptanmıştır.

-Ford Otosan, İş Bankası ve Yapı Kredi'nin YouTube kanallarında reklamlar bölümünde 1 Ocak 2019-1 Haziran 2019 tarihleri arasında bir içeriğe rastlanmamış olup, bir bulguya ulaşılamamıştır.

\section{Sonuc}

Günümüzde tüketiciler sadece ürün ve hizmetler değil, aynı zamanda bunların sahip olduğu soyut şeyleri, yani anlamları da satın almaktadır. Bu noktada markaların, günümüzde çok fazla alternatife sahip tüketicileri sadece rasyonel fayda ile ürettikleri ürün/hizmetleriyle tatmin etmeleri mümkün görünmemektedir. Markalar, tüketici tatminini sağlayarak onları sadık birer müşteriler haline getirebilmek amacıyla ikna edici iletişim mesajlarından faydalanmaktadır ve soyut olarak anlam yüklediği ürün/ hizmetlerini özellikle reklamlar aracılığıyla hedef kitleleriyle buluşturmaktadırlar.

Markalar ürün hizmetlerine anlam yükleyerek onlara tıpkı bireylerde olduğu gibi kişilik kazandırmaktadır. Böylelikle kişiliğe bürünen markalar ve ürün/hizmetleri, benzer markalar arasında farklılaşarak mesajlarını hedef kitlelerine daha etkili iletebilmektedirler. Bu noktada markalara kişilik kazandırmak amacıyla arketiplerden faydalanılmaktadır. Jung tarafından ilk kez ifade ettiği arketip kavramı (4 arketip) ilerleyen zamanlarda birçok araştırmacının dikkatini çekmiş, özellikle Mark ve Pearson'un yaptığı araştırmasıyla birlikte genişletilerek toplamda 12 arketip üzerinde yoğunlaşılmıştır.

Tüketiciler satın aldıkları markalarda kendilerinden yansımalar görmek istemektedir. Böylelikle tüketiciler, ürün/hizmetlerin yanı sıra, yaratıcılık, mizah, aşk, kahramanlık, yardımseverlik vb. gibi anlamları da satın alarak kendi kişilikleriyle markayı bütünleştirmiş olur. Çünkü, Aaker (1996)'ın vurguladığı üzere, marka kişiliği farklı hedef kitleler ile kurulan ilişki sonucunda, marka ile ilgili olarak oluşan çağrışımların bütünü olarak oluşmaktadır.

Brand Finance 2018 Türkiye Raporunu esas alınarak yapılan bu çalışma da göstermiştir ki, Türkiye'nin en değerli ilk 10 markasının \%70'i 2019 yılının ilk yarısında (1 Ocak 2019-1 Haziran 2019) YouTube kanallarında reklam filmi yayınlamış ve bu reklam yayınlayan markaların tamamı reklamlarında çeşitli arketiplere yer vermiştir. Incelenen 7 markanın (Arçelik 8, Ziraat Bankası 4, Garanti Bankası 4, Türk Telekom 4, Turkcell 4, Türk Hava Yolları 3 ve Akbank 3 adet) toplam 30 adet reklamında kullanılan arketipler ise, markaların kendilerini pazarda konumlandırma biçimleri, hedef kitlelerinin beklentileri ve sosyo-ekonomik düzeylerine göre değişkenlik göstermektedir.

Araştırmada, incelenen ulusal markaların, marka kişiliği temelli iletişim stratejilerine yönelik veriler, Fleischman (1997), Yakın (2013), Yılmaz (2018) ve Holt (2003)'ün vurguladığı üzere marka kişiliği inşa etme ve tüketici ile marka arasında duygusal bir bağ oluşturma amacıyla arketip kullanımından etkin bir biçimde yararlandıklarını ortaya koymaktadır. İncelenen ulusal markaların, YouTube platformunda paylaştıkları reklamlarda arketip kullanımına sıklıkla yer vermesi ise; Conejo (2017)'nun vurguladığı üzere, 
sosyal medya reklamlarında arketip kullanımının marka-tüketici etkileşimi sürecinde marka kişiliğinin inşası açısından yüksek bir potansiyel taşıdığını da göstermektedir.

\section{Kaynakça}

Aaker, D. (1996). Building Strong Brands. New York: The Free Press.

Aaker, J. (1997). Dimensions Of Brand Personality. Journal Of Marketing Research, 34: ss. 342-352.

Azoulay, A. ve Kapferer J. N. (2003). Do Brand Personality Scales Really Measure Brand Personality?. Brand Management, 11(2): ss. 143-155.

Balcı, Ş. ve Bekiroğlu, O. (2012). İçerikten Anlama Giden Bir Tünel Olarak İçerik Çözümlemesi: 2011 Genel Seçimlerinde Ak Parti TV Reklamları Üzerine Bir Araştırma. Ed. Özlem Güllüoğlu. Illetişim Bilimlerinde Araştırma Yöntemleri Yazılı Metin Çözümleme. Ankara: Ütopya Yayınevi. ss. 268-323.

Büyüköztürk, Ş. vd. (2018). Bilimsel Araştırma Yöntemleri. Ankara: Pegem Akademi.

Conejo, F. (2017). Improving Social Media Brand Personas Using Archetypes, Journal of Digital \& Social Media Marketing. 5(2): ss.189-202.

Erciş, A. ve Çelebi, Y. (2016). Marka Konumlandırmaları ve Tüketicilerin Marka Algılamaları. Uluslararası Sosyal Araştırmalar Dergisi, 9(45): s. 753-767.

Faber, A. M., ve Mayer, D. J. (2009). Resonance To Archetypes In Media: There's Some Accounting For Taste. Journal of Research in Personality, (43): s. 307-322.

Fleischman, M. R., (1997). Archetype Research for Advertising: A Spanish-language Example. Journal of Advertising Research, September-October: ss. 81-84.

Freud, S. (1963). Essais de Psychanalyse. Paris, France: Payot.

Furnham, A., ve Heaven, P. (1999). Personality And Social Behavior, Arnold, London.

Gardner. B. B. ve Levy S. J. (1955), "The Product And Brand", Harvard Business Review, 33:ss. 33-39.

Jensen, K. B. (2011). New Media, Old Methods, Internet Methodologies and the Online/Offline Divide. Yiğit Yavuz. (Çev). Ed. Şahinde Yavuz. Medya ve İzleyici Bitmeyen Tartışma. Ankara: Vadi Yayınları. ss. 55-83.

Jung, C. G. (1916). Psychology of the Unconscious: Study of the Transformations and Symbolisms of the Libido 'A Contribution to the History of the Evolution of Thought. (Beatrice M. Hinkle, (Çev.), NY USA: Moffat Yard And Company.

Jung, C. G. (1980). The Archetypes And The Collective Unconscious. USA: Princeton University Press.

Jung, C. G. (2005). Dört Arketip. Z. A. Yılmazer (Çev.), İstanbul: Metis Yayınları.

Jung, C. G. (2006). Analitik Psikoloji. Ender Gürol (Çev.), İstanbul: Payel Yayınları. 
Jung, C. G. (2014). Jung Psikolojisi: Bir Psikoloji \& Modern Psikanaliz Kuramı. İstanbul: E-kitap Projesi.

Holt, D. B. (2003). What Becomes An Icon Most. Harvard Business Review, 81(3): ss.43-49.

Kotler, P. ve Armstrong, G. (1989). Principles Of Marketing. New York: Prentice-Hall.

Kotler, P. (2000). Marketing Management: The Millennium Edition. USA: Prentice-Hall.

Krippendorff, K. (2003). Content Analysis: An Introduction to its Methodology. London: Sage Publications.

Mark, M., ve Pearson, C. (2001). The Hero and the Outlaw: Building Extraordinary Brands Through the Power of Archetypes. New York: McGraw-Hill.

Odabaşı, Y. ve Barış, G. (2007). Tüketici Davranışı. İstanbul: Medicat Kitapları.

Tığlı, M. (2003). Marka Kişiliği. Marmara Üniversitesi I.I.̇.B.F İşletmeBölümü Öneri Dergisi, Sayı: 20: s. 79-92.

Yakın, V. (2013). Reklamlarda Kullanılan Arketipler Aracılığıyla Marka Kişiliğinin Oluşturulması. Yayımlanmamış Doktora Tezi. Manisa: Celal Bayar Üniversitesi Sosyal Bilimler Enstitüsü.

Yakın, V. ve Ay, İ. C. (2012). Markaların Kişilik Arketiplerinin Algılanması Üzerine Bir Araştırma. The Turkish Online Journal of Design, Art andCommunication (TOJDAC), 2(3): s. 27-36.

Yavuz, E. (2004). Marka Kişiliğinin Tüketici Algısına Etkisi ve Bir Uygulama. Yayımlanmamış Yüksek Lisans Tezi. İstanbul: Marmara Üniversitesi Sosyal Bilimler Enstitüsü.

Yıldırım, A ve Şimşek, H. (2008). Sosyal Bilimlerde Nitel Araştırma Yöntemleri. Ankara: Seçkin Yayıncılık.

Yılmaz, B. F. (2018). Carl Gustav Jung'un Arketipleri Bağlamında "Persil, Magnum ve Eti Canga" Reklam Filmlerinin Çözümlemeleri. Halkla Ilişsiler ve Reklam Çalışmaları E-Dergisi, 1(1): s. 98-114.

Xara-Brasil, D. K. vd. (2018). "The Meaning Of A Brand? An Archetypal Approach," Revista de Gestao , 25(2): ss 142-159.

Woodside, G. A., Megehee, M. C., ve Sood, S., (2012). Conversations With(in) The Collective Unconscious By Consumers, Brands, And Relevant Others. Journal of Business Research, (65): ss. 594-602.

\section{Internet Kaynakları:}

Business Owners Playbook (ty). 11 Haziran 2019 tarihinde https://www.thehartford.com/ business-playbook/in-depth/choosing-brand-archetype adresinden edinilmiştir.

Fabrikbrands (2019). 11 Haziran 2019 tarihinde www.fabrikbrands.com adresinden edinilmiştir. Harvey, S. (2018). The importance of brand archetypes: Are you a lover or a ruler? 10 Haziran 2019 tarihinde http://fabrikbrands.com/the-importance-of-brand-archetypes/ adresinden edinilmiştir.

Purkiss J., ve Lee R. D., (2012). Brand You: The Archtypes, Pearson, 11 Haziran 2019 tarihinde 
http://www.brandyou.info/downloads/BY_Chapter8.pdf adresinden edinilmiştir.

The Hartford (2019). 11 Haziran 2019 tarihinde www.thehartford.com adresinden edinilmiştir.

Türkiye'nin en değerli markalarının yıllık raporu (2018). 11 Mayıs 2019 tarihinde https:// brandfinance.com/images/upload/brand_finance_turkey_100_2018.pdf adresinden edinilmiştir. 